\title{
Role of amyloid peptides in vascular dysfunction and platelet dysregulation in Alzheimer's disease
}

\author{
Ilaria Canobbio*, Aisha Alsheikh Abubaker ${ }^{\dagger}$, Caterina Visconte, Mauro Torti and Giordano Pula $^{\dagger}$
}

Department of Biology and Biotechnology, Unit of Biochemistry, University of Pavia, Pavia, Italy

Edited by:

Francesco Moccia, University of

Pavia, Italy

Reviewed by:

Dmitry Lim, Università del

Piemonte Orientale "Amedeo

Avogadro", Italy

Tiziana Casoli, Istituto Nazionale di

Riposo e Cura per Anziani, Italy

*Correspondence:

Ilaria Canobbio, Department of Biology and Biotechnology, Unit of

Biochemistry, University of Pavia,

Via Bassi 21, 27100 Pavia, Italy

e-mail: ilaria.canobbio@unipv.it

\section{${ }^{\dagger}$ Present address:}

Aisha Alsheikh Abubaker and Giordano Pula, Department of

Pharmacy and Pharmacology,

Centre for Regenerative Medicine,

University of Bath, Bath, UK
Alzheimer's disease (AD) is the most common neurodegenerative cause of dementia in the elderly. $A D$ is accompanied by the accumulation of amyloid peptides in the brain parenchyma and in the cerebral vessels. The sporadic form of AD accounts for about $95 \%$ of all cases. It is characterized by a late onset, typically after the age of 65 , with a complex and still poorly understood aetiology. Several observations point towards a central role of cerebrovascular dysfunction in the onset of sporadic AD (SAD). According to the "vascular hypothesis", AD may be initiated by vascular dysfunctions that precede and promote the neurodegenerative process. In accordance to this, AD patients show increased hemorrhagic or ischemic stroke risks. It is now clear that multiple bidirectional connections exist between $A D$ and cerebrovascular disease, and in this new scenario, the effect of amyloid peptides on vascular cells and blood platelets appear to be central to AD. In this review, we analyze the effect of amyloid peptides on vascular function and platelet activation and its contribution to the cerebrovascular pathology associated with AD and the progression of this disease.

Keywords: amyloid peptides, platelets, vascular cells, cerebrovascular disease, Alzheimer's disease

\section{ALZHEIMER'S DISEASE AND AMYLOID PEPTIDES}

Alzheimer's disease (AD) is the most invalidating neurological disorder in the elderly and affects 45 million people worldwide. In parallel with population aging, $\mathrm{AD}$ patients are expected to rise to 115 million in 2050 worldwide (World Alzheimer Report et al., 2011). ${ }^{1}$ The social and economic burden of $\mathrm{AD}$ is high and has been calculated that in the US alone 600 billion dollars per year are spent for $\mathrm{AD}$ patients' care (The Lancet Neurology et al., 2010). In the UK, dementia costs the economy more than cancer and heart disease combined (Alzheimer research UK site). Despite several promising advances in this field (Blennow et al., 2015), effective predictive markers of AD are still elusive and diagnosis relies on cognitive symptoms characteristic of the advanced stages of the disease. Brain scan and postmortem histological analysis of brain specimens remain the most reliable tools for $\mathrm{AD}$ diagnosis (Ikonomovic et al., 2008).

$\mathrm{AD}$ results in progressive loss of cognitive function and memory, which ultimately depends on extensive loss of cerebral tissue functionality linked to neuronal death (Gandy, 2005). The histological hallmarks of AD throughout the brain (mainly in the region of hippocampus and neocortex) are intracellular deposition of hyperphosphorylated form of the microtubule associated protein tau called neurofibrillary tangles (NTF) and extracellular accumulation of amyloid $\beta$ peptides (A $\beta$ peptides) in senile plaques

${ }^{1}$ http://www.alz.co.uk/
(Bloom, 2014). Deposits of $A \beta$ peptides are also observed in the cerebrovasculature, where they may develop cerebral amyloid angiopathy (CAA; Viswanathan and Greenberg, 2011).

$\mathrm{A} \beta$ peptides that accumulate in cerebral senile plaques and vessel walls derive from the metabolism of the larger glycoprotein called amyloid precursor protein (APP), which is a type 1 membrane glycoprotein expressed ubiquitously in the cells. APP isoform 695 is mainly expressed in neurons, whereas APP751 and APP770 that contain the Kunitz type serine protease inhibitory domain KPI are mainly expressed on peripheral cells and platelets (Van Nostrand et al., 1994). APP can be processed via two alternative pathways, amyloidogenic and non-amyloidogenic (Gandy, 2005). The amyloidogenic pathway produces $A \beta$ peptides by the subsequent action of $\beta$ - and $\gamma$ secretases. $\beta$-secretase proteolyses APP in the extracellular domain to generate soluble amyloid precursor protein $\beta$ ( a carboxyl terminal fragment named CTF $\beta$ (C99), which is the substrate for $\gamma$ secretase to produce $A \beta$ peptides. $\beta$ secretase, or BACE, is a membrane bound aspartyl protease, for which APP is a substrate (Vassar et al., 2014). For this reason, BACE antagonists have been proposed for treatment of $\mathrm{AD}$ (Menting and Claassen, 2014). $\gamma$ - secretase activity is contained within a molecular complex formed by the association of four essential subunits: presenilin1 or presenilin2 (either PS1 or PS2), nicastrin, presenilin-enhancer-2 (PEN-2) and anterior-pharynx-defective 1 (APH-1; Iwatsubo, 2004). The presenilins are ubiquitously 
expressed and represent the catalytic subunits of $\gamma$ - secretase, whereas the other subunits help to stabilize the complex and to recruit the substrates to be cleaved (Smolarkiewicz et al., 2013). Alternatively, APP may be proteolysed through the nonamyloidogenic pathway, via the action of $\alpha$ - and $\gamma$-secretase (Buxbaum et al., 1998). $\alpha$-secretase cleaves APP within the $\mathrm{A} \beta$ sequence, thus precluding the generation of $\mathrm{A} \beta$ peptides. Cleavage within A $\beta$ sequence of APP by $\alpha$-secretase generates soluble amino terminal fragments of 100-130 kDa (sAPP $\alpha$ ) and a carboxyl terminal fragment named $\mathrm{CTF} \alpha$ (C83), which is substrate for $\gamma$-secretase (Esch et al., 1990; Vingtdeux and Marambaud, 2012) to produce the non amyloidogenic peptide $\mathrm{p} 3$. sAPP $\alpha$ generated from the cleavage of APP by $\alpha$-secretase shows biological functions in growth regulation and neuroprotection and, in the case of forms containing the Kunitz-type serine proteinase inhibitors KPI, in blood coagulation (Xu et al., 2007). A schematic representation of APP metabolism is presented in Figure 1.

$\mathrm{A} \beta$ peptides are heterogeneous short hydrophobic peptides $(<5 \mathrm{kDa})$ ranging between 38 and 43 amino acids. Several different $A \beta$ peptide species exist, but $A \beta_{1-40}\left(A \beta_{40}\right)$ is the most abundant. $A \beta_{40}$ peptides contain 16 amino acid residues in the amino extracellular domain of APP, and 24 amino acids in the membrane-spanning domain. $A \beta_{42}$ has two additional hydrophobic residues, Ile and Ala, and accounts for only $2-5 \%$ of $A \beta$ peptides. $A \beta_{42}$ peptides are more hydrophobic and fibrillogenic, have a higher aggregation potential and are the principal species deposited in the brain (Murphy and LeVine, 2010). A $\beta$ peptides are normally generated in healthy cells (Seubert et al., 1992), but deficiencies in their clearance and/or their abnormal production and accumulation in the brain and in the cerebral blood vessels are correlated with

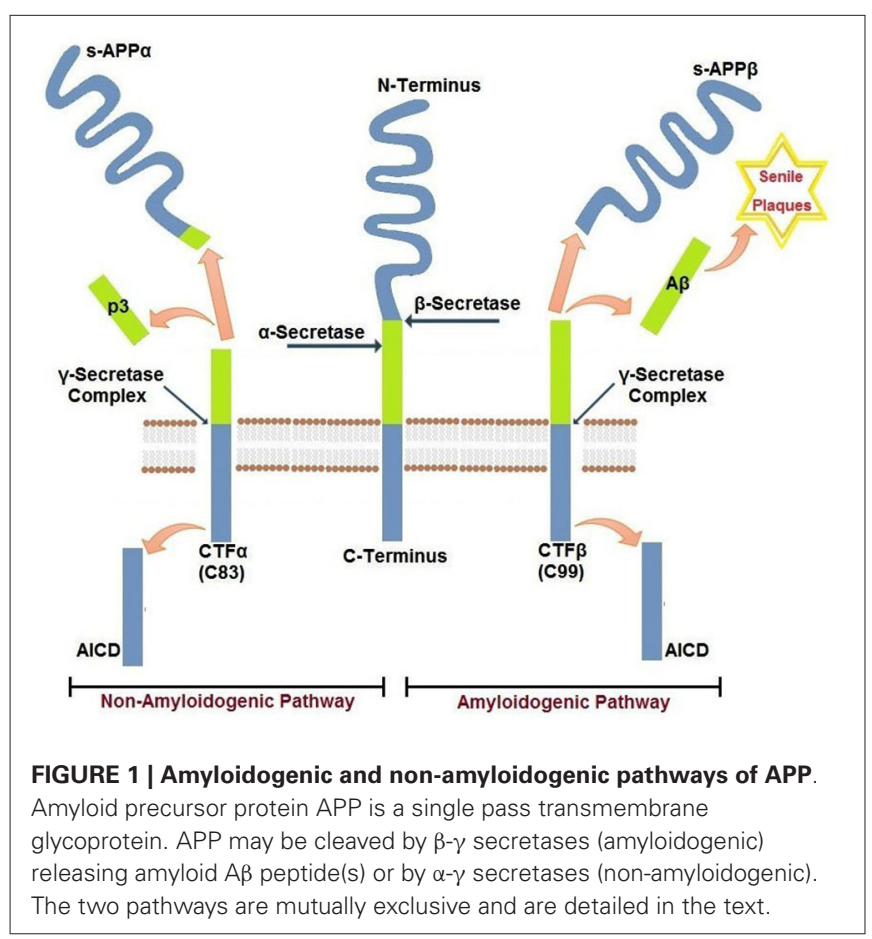

the onset of $\mathrm{AD}$. $\mathrm{A} \beta$ peptides in their monomeric forms are soluble, whereas their oligomerisation leads to the formation of intermolecular $\beta$-sheets and precipitation in senile plaques (Tjernberg et al., 1999). A $\beta$ oligomers have the ability to permeabilize the plasma membrane of different cell types, which triggers a series of cellular event leading to cell dysfunction and ultimately death. This mechanism of action is common to different amyloidogenic peptides, including A $\beta$ peptides, $\alpha$-synuclein, polyglutamine and APP (Glabe, 2006).

\section{VASCULAR PATHOLOGY IN AD AMYLOID AND VASCULAR HYPOTHESES}

According to the "amyloid cascade hypothesis", (Hardy and Higgins, 1992; Hardy and Selkoe, 2002) accumulation of A $\beta$ peptides in the brain is the central event in the pathogenesis of $\mathrm{AD}$. Abnormal deposition of $\mathrm{A} \beta$ peptides in the brain then cause plaque and tangle formation, neuronal and vascular damage, cell loss, and finally dementia. This hypothesis is supported by the finding that the familial $\mathrm{AD}$ (FAD) results from mutations in genes involved in APP metabolism: APP, PS1 and PS2 (ReznikWolf et al., 1998). These mutations cause abnormal production of $A \beta_{40}$ and $A \beta_{42}$ peptides, which accumulate in the brain and in the cerebral vessel walls. FAD affects less than $5 \%$ of $\mathrm{AD}$ cases with autosomal dominant inheritance. Symptoms develop before the age of 65 years, and the pathology is particularly aggressive and leads to death in 5-8 years.

It is noteworthy, however, that the majority of $\mathrm{AD}$ patients (95\%) develop the pathology after the age of 65 (Kennedy et al., 2003). This form of $\mathrm{AD}$ is called late onset $\mathrm{AD}$ (LOAD) or sporadic $\mathrm{AD}(\mathrm{SAD})$ and has a very complex etiology. The most common risk factor for LOAD/SAD is aging. A correlation has been demonstrated for the presence of the $\varepsilon 4$ allele for the cholesterol transporter apolipoproteinE (APOE $\varepsilon 4$ ) and the risk and the age of onset of $\mathrm{AD}$ (Michaelson, 2014). Other risk factors for LOAD/SAD are hypercholesterolemia, hypertension, Down syndrome, metabolic syndrome, diabetes, smoking and obesity (DeFronzo and Ferrannini, 1991; Gorelick, 2004; Morris et al., 2014).

The etiology of LOAD/SAD remains elusive and the role of A $\beta$ peptides is controversial (Lee et al., 2004; Sorrentino et al., 2014). Several lines of evidence point towards a central role of early vascular dysfunction in the onset of LOAD/SAD. The "vascular hypothesis" for AD was first proposed in 1993 by De La Torre, after the observation of extensive abnormalities of cerebral capillaries in $\mathrm{AD}$ brain that finally results in brain hypoperfusion and reduced cerebral blood flow (de la Torre and Mussivand, 1993). In this context, it is important to note that the first case reported by Dr. Alzheimer in 1906 revealed not only the presence of senile plaques but also the presence of cerebrovascular dysfunction. In addition, Glenner and Wong firstly isolated $\mathrm{A} \beta$ peptides from the meningeal vessels of a LOAD/SAD patient in 1984 (Glenner and Wong, 1984). This led to the coin of the term "vascular dementia", which indicates the loss of cognitive functions due to cerebral blood vessel alteration and poor blood supply to the brain (de la Torre, 2000; Kara et al., 2012). Vascular dementia and AD are correlated 
and largely overlapping phenomena (Ahtiluoto et al., 2010), and vascular dysfunctions in the brain are recognized as a contributing factor to AD (Viswanathan et al., 2009). To date, many patients with $\mathrm{AD}$ present vascular symptoms, including altered cerebral blood flow, damaged cerebral vasculature, and abnormal hemostasis (de la Torre, 2004a; Brundel et al., 2012). Tolppanen et al. demonstrated that $\mathrm{AD}$ patients, especially younger patients, have higher risk of hemorrhagic strokes (adjusted hazard ratio of 1.34; Tolppanen et al., 2013). Similarly, a recent Taiwanese population based cohort study showed that clinical diagnosis of AD is associated with considerably increased risk of stroke development (odd ratio of 1.66-1.70; Chi et al., 2013). Moreover, clinical studies indicate that asymptomatic spontaneous cerebral emboli are highly correlated with $\mathrm{AD}$ (Purandare and Burns, 2009) and that cerebral microinfarctions occur more likely in $\mathrm{AD}$ patients than in healthy controls (Brundel et al., 2012).

These observations have led to the critical question: "is $\mathrm{AD}$ a neurodegenerative or a vascular disorder?” (de la Torre, 2004b). Cerebral blood flow is reduced and conversely many vascular defects are present in patients with $\mathrm{AD}$ (Bell and Zlokovic, 2009) and vascular diseases such as atherosclerosis correlate in severity with dementia and other symptoms of LOAD/SAD (Farkas and Luiten, 2001; Roher et al., 2003; Casserly and Topol, 2004; Tibolla et al., 2010). Interestingly, vascular risk factors such as aging, hypercholesterolemia, hypertension, diabetes and obesity that predispose to atherosclerosis, stroke and cardiac disease are also associated with cerebrovascular dysfunction, which might finally results in vascular dementia and the onset of $\mathrm{AD}$ (Morris et al., 2014). Accumulating body of evidence gathered from human studies and animal models of $\mathrm{AD}$ documented that cerebrovascular dysfunction precedes the development of cognitive decline and AD pathology (de la Torre, 2010; Jellinger, 2010; Kalaria, 2010). The two-hit hypothesis has been proposed regarding $\mathrm{AD}$ pathogenesis, where vascular dysfunction plays a primary role in causing neurological injury. Cerebrovascular abnormalities associated to $\mathrm{AD}$ can result in hypoperfusion, hypoxia, focal chronic inflammation and compromised function and permeability of brain blood barrier (BBB). These injuries are exacerbated by $A \beta$ peptides deposition, which may initiate neurodegeneration and eventually cognitive decline (Zlokovic, 2005; Grammas, 2011; Kelleher and Soiza, 2013; Li et al., 2015).

To date, it has been shown that cerebrovascular dysfunction accelerates $A \beta_{40-42}$ production and deposition in the cerebral vasculature (Honjo et al., 2012) and facilitates the onset of CAA (Viswanathan and Greenberg, 2011). A $\beta$ peptides are found in plasma with the levels fluctuating widely among individuals over time both in $\mathrm{AD}$ and in healthy control (the amount of $\mathrm{A} \beta_{40}$ in healthy subjects varies between 16 to $659 \mathrm{pg} / \mathrm{ml}$, the amount of $A \beta_{42}$ from 4 to $149 \mathrm{pg} / \mathrm{ml}$ ) (Roher et al., 2009). These data are likely to be affected by the hydrophobic nature of $A \beta$ peptides, which makes the peptides bind to a variety of plasma and membrane proteins hindering their effective measurement in biological fluids. The source of $A \beta$ in plasma is uncertain. Some authors suggest that plasma $A \beta$ may derive from the central nervous system through the $\mathrm{BBB}$, but most authors agree and it is now well recognized that plasma $A \beta$ derives from endothelial and circulating cells, among them platelets ( $\mathrm{Li}$ et al., 1998; Davies et al., 2000). Circulating blood platelets are the second source of APP protein after the brain and are the major source of A $\beta$ peptides released in plasma (Li et al., 1998). Other peripheral sources of $A \beta$ peptides are skeletal muscle (Kuo et al., 2000; Van Nostrand and Melchor, 2001) and endothelial vascular cells (Kitazume et al., 2012). Interestingly, A $\beta$ peptides are able to actively pass the BBB (Deane et al., 2003, 2004), and the $\mathrm{BBB}$ damage typical of cerebrovascular pathologies is likely to increase the exchange of $\mathrm{A} \beta$ peptides between cerebral and peripheral tissues, including blood. Importantly, a recent study has demonstrated that peripheral reduction of $A \beta$ peptides is sufficient to reduce $A \beta$ levels in the brain, which confirms the extracerebral origin of plasma A $\beta$ peptides (Sutcliffe et al., 2011).

\section{AD AND VASCULAR INFLAMMATION}

A number of morphological changes have been observed in the cerebromicrovascular; these include an overall decrease in intimal tight junctions (Stewart et al., 1992), basal membrane thickening (Thal et al., 2003; Kelleher and Soiza, 2013) (particularly found in areas of $\mathrm{A} \beta$ peptides deposition) and intimal atrophy (Farkas and Luiten, 2001; Truran et al., 2014). In AD brain, substantial morphological and functional cerebrovascular abnormalities were observed including, microvasculature irregularities and atrophy, basement membrane disruption and deposition of heparin sulfate proteoglycans, collagen IV and laminin, decreased cerebrovascular network density, endothelial cell alteration i.e., increased pinocytosis, decreased levels of mitochondria and detection of elevated endothelial cell markers VCAM-1 and E-selectin (Kalaria and Pax, 1995; Farkas and Luiten, 2001; Bailey et al., 2004; Christov et al., 2008; Zuliani et al., 2008). These vascular alterations are referred to as CAA, which associates with ischemic lesions, micro- and macro-hemorrhages, and impaired cerebral blood flow. Intimal inflammation and endothelial damage are also likely to contribute to platelet stimulation in AD patients (Borroni et al., 2002a,b). Vascular risk factors, frequently present in $\mathrm{AD}$, preactivate endothelial cells and exacerbate vascular inflammation, which contributes to CAA (Zhang et al., 2013). The inflammatory proteins overexpressed in the $\mathrm{AD}$ cerebrovasculature are likely to have toxic effects on neurons, which could represent an important link between vascular inflammation and neuronal loss in AD (Tripathy et al., 2013). Failure in the clearance of $\mathrm{A} \beta$ peptides may therefore result in inflammation and neurotoxicity (Giri et al., 2000; Li et al., 2009) and CAA is likely to play a key part in brain damage and loss of cognitive skills typical of $\mathrm{AD}$ (Lee et al., 2014). In accordance to this hypothesis, human studies and animal models of $\mathrm{AD}$ document that cerebrovascular dysfunction precedes the development of cognitive decline and $\mathrm{AD}$ pathology (de la Torre, 2004b; Bell and Zlokovic, 2009; Xu et al., 2014).

Several biochemical alterations of endothelial cell physiology have been identified in response to exposure to amyloidogenic peptides (Figure 2). Amongst known inflammatory markers, cyclooxygenase 2 (COX2, a key enzyme for inflammatory reactions in platelets) expression is increased in mild cognitive 


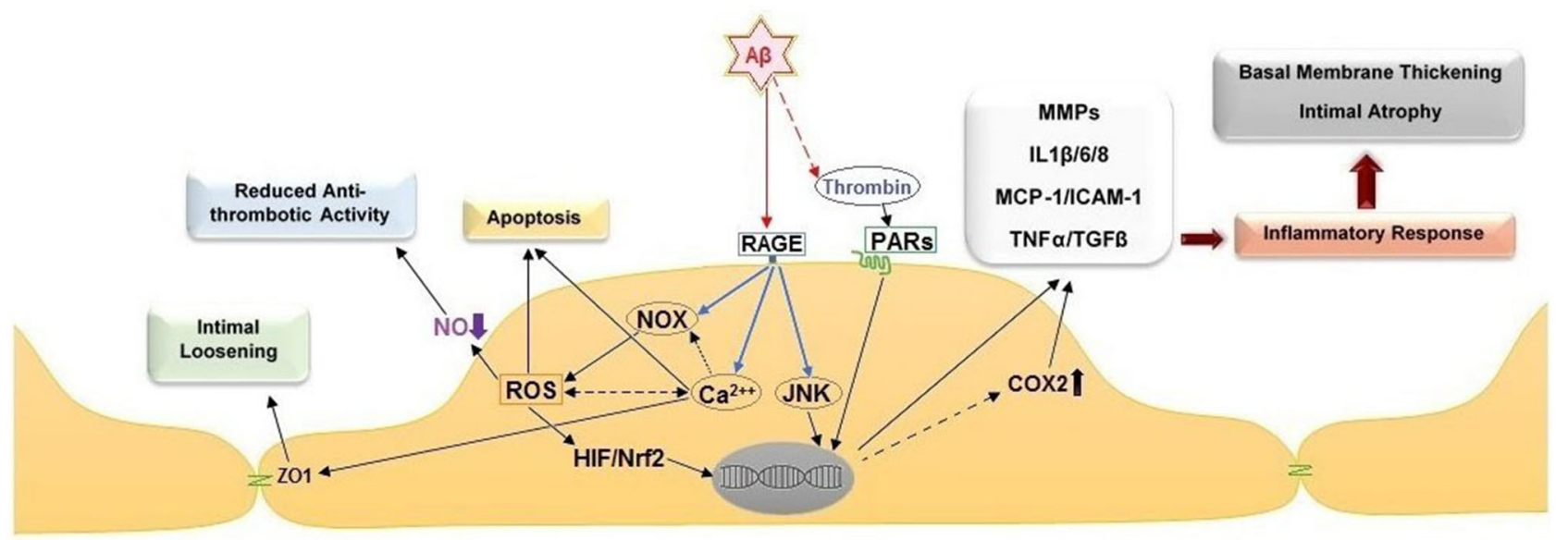

FIGURE 2 | Cellular and histological effects of amyloid peptide $\beta$ on the endothelium. Direct stimulation of the receptor for advanced glycation end products (RAGE) stimulates NADPH oxidases (NOXs), intracellular calcium increase and c-Jun N-terminal kinases (JNKs). The stimulation of NOXs and generation of reactive oxygen species (ROS) induce the activation of hypoxia-induced factor 1 (HIF) and NF-E2-related Factor 2 (Nrf2). Together with the activation of JNKs, the activity of these transcription factors leads to upregulation of pro-inflammatory genes, including cyclooxygenase 2 (COX2), metalloproteases (MMPs), interleukins 1 1 /6/8 (IL1 $\beta / 6 / 8$ ), monocyte chemoattractant protein-1 (MCP-1), intercellular adhesion molecule 1 (ICAM-1), tumor necrosis factor $\alpha$ (TNF $\alpha$ ) and transforming growth factor beta (TGF- $\beta$ ). Additional effect of ROS increase are the reduction of nitric oxide (NO) bioavailability, which leads to pro-thrombotic endothelial cell phenotype, and apoptosis. The intracellular calcium increase leads to intimal loosening via zona occludens protein 1 (ZO-1). The accumulation of thrombin in the amyloid plaques further facilitates endothelial inflammation via stimulation of the protease-activated receptors (PARs). impairment (MCI) and $\mathrm{AD}$ patients. This observation links suggestively well with several studies indicating that treatment with nonsteroidal anti-inflammatory drugs (NSAIDs) and COX2 inhibitors may reduce the risk of AD (Szekely and Zandi, 2010). Several studies indicated elevated levels of other inflammatory mediators in $\mathrm{AD}$ cerebral microcirculation, where endothelial cells overexpress adhesion molecules (MCP-1, ICAM-1, CAP37), and inflammatory and stress markers such as TNF $\alpha$, TGF- $\beta$, interleukins (IL-1 $\beta$, IL-6, IL-8) and matrix metalloproteases (MMPs; Grammas and Ovase, 2001; Grammas et al., 2002; Thirumangalakudi et al., 2006; Yin et al., 2010; Grammas, 2011). In vitro studies on cultured endothelial cells revealed that exposure to $A \beta_{40}$ increased the levels of inflammatory cytokines, including IL-6, IL-1 $\beta$, MCP-1, and GRO because of JNK-AP1 activation (Vukic et al., 2009). AD senile plaques also display elevated levels of thrombin (Akiyama et al., 1992). Besides its central role in hemostasis, thrombin is a factor with complex paracrine activity that mediates a wide array of cellular processes involving inflammation, neurotoxicity and angiogenesis. Thrombin release activates endothelial cells and enhances their expression of proinflammatory proteins such as ICAM-1 and MCP-1, angiopoietin-2 release, and up-regulation of $\alpha \mathrm{V} \beta 3$ integrin of VEGFRs expressions (Grammas and Ovase, 2001; Tsopanoglou et al., 2002). Observations obtained from in vivo and in vitro studies, showed that thrombin can cause accelerated tau protein aggregation, neuronecrosis and can incite neurotoxic effects through multiple mechanisms (Smirnova et al., 1998; Suo et al., 2003; Mhatre et al., 2004; Park and Jin, 2008; Rao et al., 2009).

\section{AD AND REDOX BALANCE IN VASCULAR CELLS}

Another significant change in endothelial cells associated with $\mathrm{AD}$ is the overexpression of receptor for advanced glycation end products (RAGE). RAGE facilitates soluble $A \beta$ peptides transport across $\mathrm{BBB}$ and across the cortical neurons intracellular space (Yan et al., 1996; Sasaki et al., 2001; Takuma et al., 2009). These findings suggest a role of RAGE in $A \beta$ deposition in the cerebral intracellular space and thereby in the enhancement of AD-associated neuronal damage (Lue et al., 2001; Takuma et al., 2009). Moreover, $A \beta$ interaction with RAGE at the BBB contributes to the up-regulation of endothelial CCR5 expression, in a dose- and time-dependent manner, via activating Egr1 transcription factor through JNK, ERK and PI3K pathways (Li et al., 2009). The upregulation of CCR5 stimulates transendothelial migration of circulating $\mathrm{T}$ cells that express high levels of CXCR2 and MIP- $1 \alpha$. MIP- $1 \alpha$ induces the opening of endothelial tight junctions (Li et al., 2009). It has been shown that increased RAGE expression facilitates the generation of reactive oxygen species (ROS) via NADPH oxidase (NOX) in cerebral endothelial cells and up regulates adhesion and pro-inflammatory molecules (Askarova et al., 2011). ROS are highly reactive molecules that promotes cell damage by direct modification of nucleic acids and proteins. One immediate consequence of increased ROS generation in cerebrovascular cells is the reduction of $\mathrm{NO}$ bioavailability through its transformation in the physiological oxidant peroxynitrite $\left(\mathrm{NO}_{3}\right.$; Beckman and Koppenol, 1996). A $\beta$ also exerts an inhibitory effect on NO signaling via binding to cell surface receptors CD36 and CD47 and inhibiting sGC/cGMP/cGK signaling 
pathways; thus contributing to the lack of NO signaling observed in AD (Miller et al., 2010). Because of the important antiplatelet and vasorelaxant activity of $\mathrm{NO}$, its reduction in the presence of increased $\mathrm{ROS}$ in $\mathrm{AD}$ brain is likely to promote platelet activation and thromboembolic consequences. Several in vitro studies on $A \beta$ peptides showed decreased NO production in endothelial cells in a dose dependent manner at $\mathrm{A} \beta$ concentrations of $\left(10^{-9}-10^{-6} \mathrm{M}\right)$ and cerebrovascular endothelium desensitization to acetylcholine, which is an endothelium dependent vasodilator, at $\mathrm{A} \beta$ concentration of $10^{-8}$ M (Grammas et al., 1995; Price et al., 2001; Hayashi et al., 2009).

In addition, ROS can activate redox-sensitive transcription factors hypoxia-inducible factor $1 \alpha$ (HIF1 $\alpha)$ and nuclear factor (erythroid-derived 2)-related factor 2 (Nrf2), which modifies gene expression of endothelial cells and can ultimately lead to the up-regulation of apoptotic/inflammatory genes (Wautier et al., 2001; Fonseca et al., 2014). Accumulative body of evidence recently shows that the main culprit behind cerebrovascular dysfunction in $\mathrm{AD}$ is oxidative stress and ROS production mainly by NOX induced by $A \beta$ that eventually triggers apoptosis in association with neurovascular inflammation (Cai et al., 2003; Park et al., 2005). High levels of pro-angiogenic gene expression have also been documented in $\mathrm{AD}$ brains using genome-wide expression profiling and includes the expression of vascular endothelial growth factor (VEGF), HIF- $1 \alpha$, angiopoietin-2 and thrombin (Pogue and Lukiw, 2004; Thirumangalakudi et al., 2006). This is likely to be an adaptive yet inefficient response to poor blood flow and ischemia in $\mathrm{AD}$ brains. In fact, $\mathrm{AD}$ cerebral tissue is characterized by reduced cerebromicrovascular density (Brown and Thore, 2011). Despite the increased expression of factors that promotes angiogenesis and neovascularization, several studies demonstrated an overall decrease in vasculature density in $\mathrm{AD}$ brains. It has been suggested that vascular-restricted mesenchyme homeobox 2 gene (MEOX2) signaling is impaired in $\mathrm{AD}$ patients, which interferes with the process of angiogenesis (Jellinger, 2002; Paris et al., 2004; Wu et al., 2005).

\section{AD AND $\mathrm{Ca}^{2+}$ HOMEOSTASIS IN VASCULAR CELLS}

In addition to ROS, different cell populations in $\mathrm{AD}$ patients and animal models of the disease documented deregulation of $\mathrm{Ca}^{2+}$ homeostasis (Berridge, 2013; Garwood et al., 2013). $A \beta$ has been shown to form cation permeable pores in the plasma membranes (Pollard et al., 1993) and it has been demonstrated that $\mathrm{A} \beta$ toxicity derives from the deregulation of $\mathrm{Ca}^{2+}$ homeostasis (Demuro et al., 2005). Mitochondrial $\mathrm{Ca}^{2+}$ overload causes mitochondrial depolarization and impairs the electron transport chain, which increases ROS generation in vascular cells (Carvalho et al., 2009). $\mathrm{Ca}^{2+}$ overload can directly activate NOXs (De Bock et al., 2013) and contribute to the redox stress of $\mathrm{AD}$ cerebral tissue. $\mathrm{Ca}^{2+}$ modulation seems to be critical for the onset of redox stress in endothelial cells. $A \beta_{40}$ induces mitochondria-mediated apoptotic endothelial cell death pathway involving ER-to-mitochondria $\mathrm{Ca}^{2+}$ transfer, decrease of mitochondrial membrane potential, and release of proapoptotic factors (Fonseca et al., 2013). Recent studies showed that short-term treatment with a toxic dose of $A \beta_{40}$ inhibits
$\mathrm{Ca}^{2+}$ retention in the endoplasmic reticulum and enhances adenosine triphosphate (ATP)-stimulated release of intracellular $\mathrm{Ca}^{2+}$ (Fonseca et al., 2014). Importantly, A $\beta$-RAGE interactions in cultured endothelial cells increase intracellular $\mathrm{Ca}^{2+}$ and alter tight junction proteins through the $\mathrm{Ca}^{2+}$-calcineurin pathway (Kook et al., 2012). This phenomenon is responsible for the reduction of zonula occludin-1 (ZO-1) expression and increased MMP secretion observed in cultured endothelial cells and can ultimately be the cause of enhanced MMP secretion and loss of vascular integrity in the vicinity of $A \beta$ plaques in animal models of $\mathrm{AD}$ (Kook et al., 2012). The resulting A $\beta$-dependent alteration in the integrity of the BBB may play a significant role in the transport and accumulation of $A \beta$ peptides from the circulation to the brain parenchyma.

\section{PLATELET PATHOLOGY IN AD APP AND A $\beta$ PEPTIDES IN PLATELETS}

The bidirectional correlations between $\mathrm{AD}$ and vascular diseases points to an important role for non-neuronal cells and extraneuronal generation of $A \beta$ peptides in the development of AD. Circulating platelets, which are anucleate cells responsible for hemostasis and thrombosis, are good candidates for the link between vascular diseases and AD. Platelets express mainly the APP isoforms 751 and 770. These isoforms contain the 56 amino acids long Kunitz type serine protease inhibitors domain KPI, which is known to inhibit serine proteases including those of the coagulation cascade (Van Nostrand et al., 1989; $\mathrm{Xu}$ et al., 2005, 2007). In addition, platelets express all the enzymatic machinery responsible for APP metabolism and for the generation of $\mathrm{A} \beta$ peptides (Evin et al., 2003; Catricalà et al., 2012). In physiological conditions, platelets metabolize APP through the non-amyloidogenic pathway: $\alpha$-secretase is activated by $\mathrm{Ca}^{2+}$ and calmodulin (Canobbio et al., 2011) and releases soluble APP $\alpha$. To a lesser extend platelets also release $A \beta$ peptides. The main species of $A \beta$ released from activated human platelets is $A \beta_{40}$, while the predominant form in neuronal plaques is $A \beta_{42}$. Immunoassay analysis has revealed that the inactivated platelets had an average of $84 \mathrm{ng} / \mathrm{g}$ tissue of $\mathrm{A} \beta_{40}$ and activated platelets contained an average of $57 \mathrm{ng} / \mathrm{g}$ tissue, while in both cases there were very low levels of $A \beta_{42}: 1.6 \mathrm{ng} / \mathrm{g}$ tissue and $1.7 \mathrm{ng} / \mathrm{g}$ tissue, respectively (Kokjohn et al., 2011). APP fragments and $\mathrm{A} \beta$ peptides are stored in platelet $\alpha$-granules as revealed by immune electron microscopy (Li et al., 1994) and sucrose density gradient (Van Nostrand et al., 1990), and are released upon stimulation with physiological agonists (Li et al., 1994). Increasing evidence suggests that released $A \beta$ peptides are able to activate platelets and promote platelet adhesion and aggregation (Shen et al., 2008a,b; Canobbio et al., 2013, 2014). This eventually results in enhanced thrombus formation in vitro and in vivo (Gowert et al., 2014; Sonkar et al., 2014). On the contrary, soluble APP fragments have been shown to regulate thrombosis and hemostasis in vivo (Xu et al., 2005, 2007).

The relatively abundant concentration of APP in platelets (9300 copies/platelet) (Rowley et al., 2011) and the predominant presence in platelets of the KPI containing isoforms suggest that APP may have a physiological role, mainly in events 
associated with coagulation (Van Nostrand et al., 1992; Xu et al., 2005). A minority (10\%) of APP is expressed as an intact glycoprotein on the platelet surface where it may act as a receptor on the platelet surface (Kang et al., 1987; Li et al., 1994). Fibrillar A $\beta$ but not unassembled A $\beta$, specifically binds to APP (Lorenzo et al., 2000; Van Nostrand et al., 2002; Sola Vigo et al., 2009). APP also can bind to sulfated proteoglycans, laminin, collagen and integrin like receptor, suggesting a role in cell-cell and cell- matrix interactions (Breen et al., 1991; Ghiso et al., 1992; Milward et al., 1992; Beher et al., 1996; Williamson et al., 1996; Verdier and Penke, 2004). Moreover several studies have reported that treatment of neuronal cell with monoclonal antibody $22 \mathrm{C} 11$ directed toward the $\mathrm{N}$ terminal domain of APP can stimulate G protein activity (Okamoto et al., 1995) and/or cause the dimerization of APP (Scheuermann et al., 2001). Notably, APP metabolism resembles that of Notch (Nakayama et al., 2011): in the canonical Notch signaling pathway, $\gamma$-secretase cleaves Notch in the plasma membrane and release an intracellular domain that shows activity in the nucleus through binding to transcription factors. Since platelets are anucleate cellular fragments this consideration deserve further investigation.

APP is proteolytically cleaved during platelet activation ( $\mathrm{Li}$ et al., 1998; Evin et al., 2003). The released soluble APP fragment that contain KPI domain was firstly identify as Protease Nexin 2 PN-2, a chymotrypsin inhibitor and regulator of blood coagulation (Van Nostrand et al., 1989). More recently it has been shown by the same authors that PN-2 coincide with soluble APP fragment containing KPI (Van Nostrand et al., 1992). Soluble APP inhibits the activity of the blood coagulation factors IXa, XIa, and $\mathrm{Xa}$, and, to a lesser extent, of factor VIIa-tissues factor complex (Smith et al., 1990; Van Nostrand et al., 1992; Schmaier et al., 1995; Scandura et al., 1997) and may therefore play a role in the coagulation cascade, thus modulating hemostasis following vascular injury by limiting thrombosis. Xu et al. generated specific transgenic mice which expressed human APP770 in platelets, under the control of rPF4 promoter. Transgenic mice express 2 fold higher APP770 amount in platelets, but not in other analyzed tissues. They investigated the APP function comparing Tg-rPF4/APP mice with wild type mice and with mice which do not express APP at all (APP KO) and demonstrated that KPIcontaining forms of APP regulates cerebral thrombosis in vivo in a carotid artery thrombosis and in experimental intracerebral hemorrhage (Xu et al., 2005, 2007). In accordance to this, recombinant soluble APP has been shown to inhibit platelet aggregation and secretion induced by ADP and adrenaline in vitro (Henry et al., 1998).

\section{A $\beta$ PEPTIDE-DEPENDENT ACTIVATION OF PLATELETS}

It has been widely demonstrated by several authors that $A \beta$ peptides are able to activate platelets (Figure 3 ). The first study date back to 2007 and analyzed the effects of misfolded proteins on platelet activation. Herzenik et al. showed that proteins with amyloid properties, including $\mathrm{A} \beta$ peptides, activate platelets. Fibrillar $A \beta$ peptide induces platelet aggregation through the scavenger receptor CD36 and GPIb $\alpha$, and activation of intracellular signaling pathways involving p38MAPK, cyclooxygenase1 (COX1) and thromboxane A2 production (Herczenik et al., 2007). More recently, the ability of amyloid peptides to activate platelets has been investigated using the synthetic peptide $A \beta_{25-35}$. This undecapeptide is located in the intermembrane domain of APP and retains the toxic properties of the entire peptide representing the biologically active region of $A \beta$ (Kang et al., 1987). A $\beta_{25-35}$ toxicity resides in the ability to form oxygen radicals, nitric oxide and to disrupt calcium homeostasis (Kaminsky et al., 2010). In preliminary studies, $A \beta_{40}$ and $A \beta_{25-35}$ showed equal potencies in inducing platelet activation (Shen et al., 2008a). Exogenous $A \beta_{25-35}(1-2 \mu \mathrm{M})$ potentiated agonistinduced platelet aggregation induced by collagen and ADP, and at higher concentrations $(2-10 \mu \mathrm{M}) \mathrm{A} \beta_{25-35}$ itself directly promotes aggregation, and activation of intracellular signaling pathways through thrombin receptor PAR1 activation of p38 MAPK and cytosolic PLA 2 , and TxA2 formation (Shen et al., 2008a). In addition, the same authors demonstrated that $A \beta_{25-35}$ stimulates PLC/PKC activation and $\mathrm{Ca}^{2+}$ mobilization (Shen et al., 2008b). $A \beta_{25-35}$ also induced the activation of small GTPase RhoA and phosphorylation of myosin light chain kinase, which leads to cytoskeletal reorganization and results in shape change, granule release, integrin activation and clot retraction. An essential role for $\mathrm{Ca}^{2+}$ and ADP in $\mathrm{A} \beta$-induced platelet activation and thrombus formation has been recently demonstrated by our group (Canobbio et al., 2014). We have demonstrated that the first event in $A \beta$-induced platelet activation is the increase of intracellular $\mathrm{Ca}^{2+}$ concentration. Our results confirmed and extended previous observations by Galeazzi et al., on $\mathrm{A} \mathrm{\beta}_{25-35^{-}}$ induced intraplatelet $\mathrm{Ca}^{2+}$ mobilization (Galeazzi et al., 2000). $\mathrm{A} \beta$-induced intracellular $\mathrm{Ca}^{2+}$ movements rely on the presence of extracellular $\mathrm{Ca}^{2+}$, this result is in line with the evidence that $\mathrm{A} \beta$ is able to form cation permeable pores in the plasma membranes (Pollard et al., 1993) and that $A \beta$ toxicity derives from the deregulation of $\mathrm{Ca}^{2+}$ homeostasis (Demuro et al., 2005). Intracellular $\mathrm{Ca}^{2+}$ increase in platelets promotes acto-myosin cytoskeletal reorganization, granule secretion and ADP release. Once released ADP is able to reinforce and promote platelet activation in term of phosphorylation of selected signaling proteins, mainly the non receptor tyrosine kinase Syk, PI3K, PKC and MLC, activation of the small GTPase Raplb, inside-out activation of integrin $\alpha_{I I b} \beta_{3}$, and finally aggregation (Canobbio et al., 2014).

We have demonstrated that platelets are also able to adhere and spread over immobilized $A \beta_{25-35}$ as well as $A \beta_{40}$ and $A \beta_{42}$, to accelerate platelet adhesion over collagen (Canobbio et al., 2013; Gowert et al., 2014), and to increase platelet spreading over fibrinogen (Sonkar et al., 2014). Interestingly, platelets adhere to $A \beta$ peptides independently of ADP but are able to activate several intracellular signaling pathways associated with platelet stimulation dependently on the release of ADP. A $\beta$ peptides also enhance adhesion to collagen under shear (Canobbio et al., 2014) and potentiates thrombus formation in vivo, as revealed in a mouse model of pulmonary thromboembolism (Sonkar et al., 2014). The effect of $A \beta$ in promoting platelet activation in vivo was confirmed in injured carotid artery model (Gowert et al., 2014). More interestingly, the effect of amyloid peptides was analyzed in APP transgenic mice. APP23 and APP Dutch mice are known 


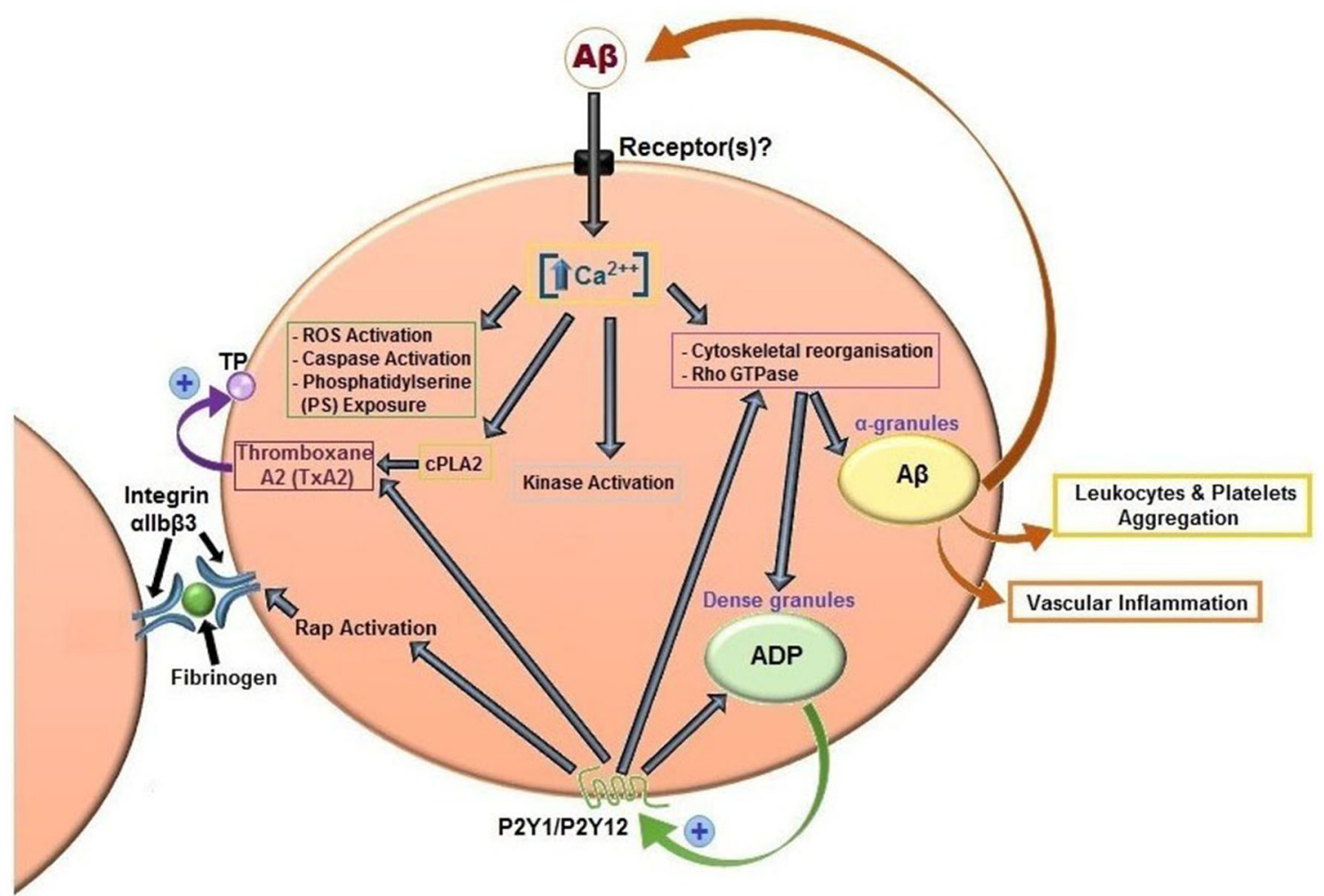

FIGURE 3 | A $\beta$ peptides-induced platelet activation. $A \beta$ peptides present in plasma activate platelets inducing activation of PLC/PKC and intracellular $\mathrm{Ca}^{2+}$ movement, granule secretion, kinase activation, rap1b mediated-integrin activation and aggregation. A $\beta$ peptides released from $\alpha$-granules, ADP released by dense granules, and formation of $T \times A_{2}$ reinforce platelet activation. A $\beta$ peptides also promotes ROS formation, caspase activation and membrane scrambling. Activated platelets recruit leukocytes and promotes vascular inflammation. to develop CAA upon aging and to deposit amyloid peptides in the cerebral vessel walls. Gowert et al. analyzed brain of these transgenic mice for $\mathrm{A} \beta$ deposition and platelet recruitment and demonstrated that platelets adhere to vascular amyloid plaques with time and that sustained platelet recruitment may lead to full occlusion of the vessel (Gowert et al., 2014).

$\mathrm{A} \beta$ peptides regulate phosphatidylserine exposure, micro -particles production and caspase activation, suggesting a transition of platelets from activation to apoptosis (Gowert et al., 2014). Recently, it has been demonstrated that mitochondrial respiration is increased in $\mathrm{A} \beta$-stimulated platelets (Sonkar et al., 2014). In addition, ROS generation in platelets is significantly increased by exposure to $\mathrm{A} \beta$ peptides (Gowert et al., 2014). Moreover, cytochrome $\mathrm{c}$ oxidase, an enzyme that belongs to the complex IV of the respiratory chain, has been observed to be diminished in platelets and hippocampal mitochondria of $\mathrm{AD}$ patients (Bosetti et al., 2002). This result was confirmed by other studies, and is correlated with increased ROS formation in AD platelets (Cardoso et al., 2004). Taken together, these studies point toward an increased oxidative stress in $\mathrm{AD}$ patients. There is therefore the possibility that $\mathrm{A} \beta$ peptides stimulate/increase platelet activation by inducing a state of redox stress, which has been shown to increase platelet responsiveness. For example, $\mathrm{O} 2$ - has been suggested to stimulate platelet hyperactivity in anoxia/reoxygenation conditions (Leo et al., 1997) and hypercholesterolemia (Stokes et al., 2007). The dependence of platelet activation on ROS generation explains the inhibition of platelets and the anti-thrombotic effect of antioxidants (Freedman, 2008) or ROS-generating enzyme inhibitors (Vara et al., 2013).

Table 1 summarize the effects of $\mathrm{A} \beta$ peptides on platelet activation.

\section{ANIMAL MODELS OF AD AND PLATELET AND VASCULAR (DYS)FUNCTIONS}

Since the formulation of the "amyloid cascade hypothesis" and the discovery of mutations correlated with FAD, several $\mathrm{AD}$ transgenic mice have been developed to study the pathophysiological role of APP and A $\beta$ peptides. In most cases, $\mathrm{AD}$ transgenic mice express mutant human APP or PS1/PS2 genes (one single or more mutations correlated with $\mathrm{AD}$ onset in FAD). In addition, mice that do not express APP have been generated to investigate the physiological role of APP in cellular signaling. The number of murine model for AD is exponentially growing and for an extensive list of $\mathrm{AD}$ model mice we suggest to refer to http://www.alzforum.org/research-models. These mice have been extensively studied as a model for the onset of $\mathrm{AD}$, and to investigate the mechanism underlying amyloid deposition 
Table 1 | Principal molecular effects of amyloid peptides on platelets

\begin{tabular}{|c|c|c|}
\hline Amyloid peptide & Molecular effects on platelets & References \\
\hline \multirow[t]{6}{*}{$A \beta_{1-40}$} & promotes platelet aggregation & Herczenik et al. (2007) \\
\hline & $\begin{array}{l}\text { promotes ROS formation, caspase activation, annexin } \vee \text { exposition } \\
\text { and membrane scrambling }\end{array}$ & Gowert et al. (2014) \\
\hline & promotes platelet adhesion under static and dynamic flow conditions & Canobbio et al. (2013), Gowert et al. (2014) \\
\hline & increases platelet adhesion in an injured carotid artery model & Gowert et al. (2014) \\
\hline & modulates soluble $A \beta$ into fibrillar $A \beta$ & Gowert et al. (2014) \\
\hline & recruits platelets to vascular amyloid plaques & Gowert et al. (2014) \\
\hline \multirow[t]{15}{*}{$A \beta_{25-35}$} & induces platelet adhesion in static conditions & Canobbio et al. (2013) \\
\hline & fastens platelet spreading over collagen & Canobbio et al. (2013) \\
\hline & increases platelet spreading over fibrinogen & Sonkar et al. (2014) \\
\hline & increases adhesion to collagen under shear & Canobbio et al. (2014), Sonkar et al. (2014) \\
\hline & promotes platelet aggregation & $\begin{array}{l}\text { Shen et al. (2008b), Canobbio et al. (2014), } \\
\text { Sonkar et al. (2014) }\end{array}$ \\
\hline & $\begin{array}{l}\text { potentiates platelet aggregation induced by } \\
\text { collagen and ADP }\end{array}$ & Shen et al. (2008a) \\
\hline & promotes $\mathrm{Ca}^{2+}$ mobilization and granule secretion & $\begin{array}{l}\text { Galeazzi et al. (2000), Canobbio et al. (2014), } \\
\text { Sonkar et al. (2014), }\end{array}$ \\
\hline & activates PLC and PKC & Shen et al. (2008b) \\
\hline & activates Syk, PI3K/Akt, MAP kinases & Canobbio et al. $(2013,2014)$ \\
\hline & induces RhoA and Rap1b activation & Canobbio et al. (2014), Sonkar et al. (2014) \\
\hline & induces Rap1b and integrin activation & Canobbio et al. (2014), Sonkar et al. (2014) \\
\hline & triggers hydroxyl radical formation & Shen et al. (2008b) \\
\hline & induces clot retraction & Sonkar et al. (2014) \\
\hline & shortens platelet plug formation in mesenteric venules in mice & Shen et al. (2008b) \\
\hline & induces thrombus formation in a model of pulmonary thromboembolism & Sonkar et al. (2014) \\
\hline
\end{tabular}

in brain parenchyma and cerebral vessels, their correlation with cognitive impairment, and to develop new therapeutic strategy. However, only few of these murine models have been utilized for analysis of possible peripheral platelet and vascular dysfunctions. The prothrombotic phenotype observed in $\mathrm{AD}$ patients and related to pre-activated platelets has been demonstrated in $\mathrm{AD}$ transgenic mouse models. Recently, Jarre et al. analyze platelet activation in APP23 mice which carry human APP751 containing the Swedish (KM670/671NL) under the neuronal Thy promoter. These mice deposit $A \beta$ peptides in the brain parenchyma and in the cerebral vessel walls developing CAA upon aging. In this study the authors have demonstrated that platelets of aged Alzheimer transgenic mice APP23 are in a pre-activated state and respond with enhance platelet activation upon stimulation. This finally results in a pro-thrombotic phenotype with altered hemostasis and increased thrombus formation in vivo (Jarre et al., 2014).

Not only platelets, but also cerebrovasculature is activated in AD transgenic mice. Grammas et al. analyzed two transgenic AD animal models: AD2576APPSwe and La Ferla3xTG which overexpressed $A \beta$ in the brain and demonstrated that brain endothelial cells overexpressed $\mathrm{A} \beta$, thrombin, tumor necrosis factor $\alpha$, interleukin- $1 \beta$ and interleukin 6 and MMP9 (Grammas et al., 2014). Inflamed endothelial cells also release APP770 (Kitazume et al., 2012). A $\beta$ and thrombin expressed from endothelial cells in turn strengthen platelet activation thus reinforcing chronic inflammation and thrombus formation.

\section{ANTI PLATELET THERAPIES AND AD}

$\mathrm{A} \beta$ peptides released by platelets and endothelial cells result in platelet activation and vascular inflammation with dangerous consequences for the progression of $\mathrm{AD}$. With this background, it seems reasonable that the use of antiplatelet agents and/or NSAIDs may slow down AD. We have previously reported in this review that treatment with $\mathrm{COX} 2$ inhibitors may reduce the risk of AD (Szekely and Zandi, 2010). Epidemiological studies in the past have suggested that patients taking NSAIDs or aspirin display some level of protection from $\mathrm{AD}$ (Henderson et al., 1997; Aisen et al., 2000; Broe et al., 2000; in 't Veld et al., 2002; Thal et al., 2005; ADAPT Research Group et al., 2007). Aspirin is the most common anticoagulant used in prevention of stroke and myocardial infarction (Yeung and Holinstat, 2012; Zhang et al., 2013). Aspirin is an irreversible inhibitor of cyclooxygenase 1 that catalyzes the synthesis of an important platelet agonist thromboxane A2 (Loll et al., 1995). At high doses (5 g per day) aspirin inhibits prostaglandin production by white blood cells and has therefore anti-inflammatory action, whereas at low doses (75 $\mathrm{mg}$ ) per day has mainly anti platelet activity. Aspirin is commonly used in the treatment of vascular dementia (Molnar et al., 1998). The AD 2000 collaborative group analyzed for 3 years the effect of low dose aspirin daily administration on 156 AD patients compared to $154 \mathrm{AD}$ patients who did not take aspirin. The outcomes evaluated were cognition and functional ability. The results showed no benefits of aspirin on the progression of $\mathrm{AD}$ in the analyzed subjects. On the contrary, $8 \%$ of patients taking aspirin had serious bleed and $2 \%$ of patients in the aspirin group had fatal cerebral bleed (AD2000 Collaborative Group et al., 2008). These results advice against the use of aspirin in AD, since the risks overweigh any benefits. However, more studies on aspirin or other antithrombotic drugs are necessary to understand the potential of these drugs in the treatment of $\mathrm{AD}$. It is conceivable 
that the administration of antithrombotic or anti-inflammatory drugs is not effective on $\mathrm{AD}$ when the pathology is overt, but may be important in prevention of the disease in individuals at risk.

\section{PLATELET ABNORMALITIES IN AD}

Many alterations have been observed in platelets from $\mathrm{AD}$ patients compared to age matched control subjects, but attention must be taken when considering the data found in the literature. The most important and reliable changes observed in platelets from $\mathrm{AD}$ patients are reduced APP ratio, alteration of $\alpha$ - and $\beta$-secretase expression or activity that result in abnormal APP metabolism through the amyloidogenic pathway, and enhanced platelet activation. In addition, changes in expression and/or activity of Monoamine oxidase B (MAO-B), cytochrome $\mathrm{c}$ oxidase, and cicloxygenase 2 have been reported in platelets isolated from $\mathrm{AD}$ patients. For a comprehensive and exhaustive analysis of alterations in platelets from $\mathrm{AD}$ patients refer to the recent paper by Veitinger et al. (2014).

\section{Altered APP ratio}

APP is present on plasma membrane as an intact glycoprotein of about $110 / 130 \mathrm{kDa}$ and as soluble fragments of different length in platelet $\alpha$-granules. Based on the electrophoretic mobility of anti-APP antibody 22C11-immunoreactive bands it is possible to reveal at least two isoforms of APP in platelets: a higher band at $130 \mathrm{kDa}$ and a lower band at about $106 / 110 \mathrm{kDa}$. The difference in electrophoretic mobility between the $130 \mathrm{kDa}$ and the $106-110 \mathrm{kDa}$ bands has been attributed to the presence or absence of KPI, respectively. The APP upper to lower band ratio is lower in platelets from patients affected by MCI and SAD compared to platelet prepared from control subjects and patients affected by other kind of dementia (Di Luca et al., 2000; Borroni et al., 2005, 2010). The altered APP ratio in platelets shows a positive and specific correlation to the progression of the disease. This correlation is also present in preclinical stages of $\mathrm{AD}$, suggesting that this can be as a useful biomarker for $\mathrm{AD}$.

\section{Altered secretase activation and APP metabolism}

Platelets metabolize APP preferentially through nonamyloidogenic $\alpha$-secretase pathway. In platelets from $\mathrm{AD}$ patients, the expression of $\alpha$-secretase candidate ADAM10 is decreased compared to healthy subjects (Colciaghi et al., 2002; Tang et al., 2006). On the other hand, an increased $\beta$-secretase activity has been indirectly shown by a decreased ratio of its $37 / 56 \mathrm{kDa}$ fragments (Colciaghi et al., 2004; Tang et al., 2006). The increased $\beta$-secretase activity was also demonstrated directly by enzymatic assay in the early stage of $\mathrm{AD}$ and $\mathrm{MCI}$ patients compared to control (Liu et al., 2007; Johnston et al., 2008), and by increased level of $\beta$-secretase product sAPP $\beta$ (Colciaghi et al., 2004). Taken together, this switch from non-amyloidogenic to amyloidogenic in the APP pathway is likely to be responsible for the increase in platelet-derived $A \beta$ peptides generation.

\section{Monoamine oxidase-B activity}

MAO-B is responsible for the degradation of neurotransmitters in the nervous system (e.g., dopamine) and expressed in platelets (Paasonen et al., 1964). Several studies independently described increase in MAO-B expression and activity in brain and platelets of AD patients (Adolfsson et al., 1980; Bongioanni et al., 1997; Mészáros et al., 1998). The molecular causes of this change are currently unknown.

\section{Platelets are preactivated in AD patients}

More than ten years ago, Sevush et al analyzed platelet activation in 91 patients with probable $\mathrm{AD}$ and 40 age-matched control subjects. Groups were compared for percentage of circulating platelet aggregates, surface expression of P-selectin ( $\alpha$ granule marker), formation of leukocyte-platelet complexes, and presence of circulating platelet microparticles. The results showed a significant increase in platelet aggregates, leukocyteplatelet complexes and P-selectin expression in resting platelets of $\mathrm{AD}$ patients demonstrating that platelets of patients with $\mathrm{AD}$ exhibit greater basal activation than those of controls (Sevush et al., 1998). More recently, Stellos et al. demonstrated that integrin $\alpha_{I I b} \beta_{3}$ is activated and P-selectin is expressed on plasma membrane in unstimulated platelets from $\mathrm{AD}$ subjects compared to control (Stellos et al., 2010; Laske, 2012). More interestingly, in one-year follow up study platelet activation parameters correlate with the rate of cognitive decline and antiplatelet therapy reduced cognitive decline in AD patients (Laske et al., 2010; Sakurai et al., 2013). As we previously reported, activated platelets have been shown to adhere to cerebral vascular deposits of $A \beta$ in $A D$ transgenic mice models, which are known to develop CAA upon aging. Sustain platelet recruitment to vascular amyloid plaques results in occlusion of the vessels (Gowert et al., 2014). The same authors also demonstrated that platelets are able to process soluble synthetic $A \beta$ into fibrillar $A \beta$ increasing its neurotoxicity in culture, which suggests an active role of platelets in promoting neuronal death in AD. Platelet localization at the site of cerebrovascular injury and in CAA lesions has been observed in several other studies, which demonstrated localization of activated platelets with deposit of $A \beta$ peptides (Roher et al., 2009). This is likely to play an important role in the establishment of a vicious circle of platelet activation, $A \beta$ release and neuronal cell death. Once activated, platelets can release $A \beta_{40}$ in the circulation, increasing its local concentration and contributing to accumulation of amyloid peptides in the vessel of the cerebrovasculature. Amyloid accumulation also induces microvascular inflammation (Grammas and Ovase, 2001). Platelet deposition in the cerebral microvasculature may account for the hemostatic abnormalities observed in $\mathrm{AD}$ (Wilkerson and Sane, 2002).

\section{Higher levels of "coated" platelets}

Another important parameter of platelet activation is the presence of increased levels of coated platelets in $\mathrm{AD}$ patients. Coated platelets are a subset of activated platelets observed upon dualagonist stimulation with collagen and thrombin characterized by high pro-coagulant activity (Dale, 2005). Prodan et al. demonstrated that coated platelets expressed high levels of full-length APP on their surface compared to single agoniststimulated platelets (Prodan et al., 2006). Coated platelets are increased in early stages of $\mathrm{AD}$, are elevated in patients with amnestic as compared to nonamnestic MCI, and their 
numbers correlate with disease progression in AD (Prodan et al., 2007, 2008). Coated platelets are also altered in patients with cerebrovascular disease and have been show to potentiate inflammation. These data suggest a role of coated platelets as a sensitive biomarker of AD (Prodan et al., 2009).

\section{Coagulation abnormalities in AD}

Besides platelet hyper activation, coagulation is also impaired in $\mathrm{AD}$ patients. In particular it has been observed that $\mathrm{A} \beta$ is able to bind fibrinogen and that fibrin clot formed in the presence of $A \beta$ are more stable and more resistant to degradation during fibrinolysis (Ahn et al., 2010; Cortes-Canteli et al., 2010). After $\mathrm{BBB}$ alterations fibrinogen may deposit to brain blood vessel and accumulate in CAA and parenchyma in $\mathrm{AD}$ patients, and in $\mathrm{AD}$ mouse models (Paul et al., 2007). This could finally results in altered cerebral blood flow and worsening of the pro-thrombotic phenotype in cerebral microvasculature of AD patients.

\section{CONCLUSIONS AND FUTURE DIRECTIONS}

$\mathrm{AD}$ is associated with platelet and vascular abnormalities. Our understanding of the mechanisms underlying thrombosis and angiopathy associated with $\mathrm{AD}$ is growing exponentially. Several molecular mechanisms that explain microvascular alterations associated with $\mathrm{AD}$ have been undercovered. Although the role of tau protein in neuronal death and cognitive ability loss is also central in $\mathrm{AD}$ development, the accumulation of amyloid peptides is closely related to the vascular abnormalities associated with this disease. Therefore, this was the subject of this literature review.

Future challenges in this field will be to understand fully the relevance of the microvascular symptoms of $\mathrm{AD}$ in dementia development and to target them in order to improve the management of this debilitating disease. This will require a truly multidisciplinary effort with basic scientists and clinicians from different areas of research (i.e., neuroscience, cardiovascular sciences and cell biology) collaborating towards the clarification of the complex etiology of AD. Biomedical research into the vascular aspects of $\mathrm{AD}$ provides new hopes for early disease diagnosis and the development of novel clinical strategies to reduce the rate of cognitive function loss following diagnosis.

\section{ACKNOWLEDGMENTS}

This work was supported by ARUK (Alzheimer's Research UK) [grant number PPG2013B-8 (to GP and IC)] and Biotechnology and Biological Sciences Research Council [grant number BB/J002690/1 (to GP)].

\section{REFERENCES}

AD2000 Collaborative Group, Bentham, P., Gray, R., Sellwood, E., Hills, R., Crome, P., et al. (2008). Aspirin in Alzheimer's disease (AD2000): a randomised openlabel trial. Lancet Neurol. 7, 41-49. doi: 10.1016/s1474-4422(07)70293-4

ADAPT Research Group, Lyketsos, C. G., Breitner, J. C., Green, R. C., Martin, B. K., Meinert, C., et al. (2007). Naproxen and celecoxib do not prevent AD in early results from a randomized controlled trial. Neurology 68, 1800-1808. doi: 10 . 1212/01.wnl.0000260269.93245.d2

Adolfsson, R., Gottfries, C. G., Oreland, L., Wiberg, A., and Winblad, B. (1980). Increased activity of brain and platelet monoamine oxidase in dementia of Alzheimer type. Life Sci. 27, 1029-1034. doi: 10.1016/0024-3205(80)90025-9

Ahn, H. J., Zamolodchikov, D., Cortes-Canteli, M., Norris, E. H., Glickman, J. F., and Strickland, S. (2010). Alzheimer's disease peptide beta-amyloid interacts with fibrinogen and induces its oligomerization. Proc. Natl. Acad. Sci. U S A 107, 21812-21817. doi: 10.1073/pnas.1010373107

Ahtiluoto, S., Polvikoski, T., Peltonen, M., Solomon, A., Tuomilehto, J., and Winblad, B. (2010). Diabetes, Alzheimer disease and vascular dementia: a population-based neuropathologic study. Neurology 75, 1195-1202. doi: 10. 1212/WNL.0b013e3181f4d7f8

Aisen, P. S., Davis, K. L., Berg, J. D., Schafer, K., Campbell, K., and Thomas, R. G. (2000). A randomized controlled trial of prednisone in Alzheimer's disease. Alzheimer's disease cooperative study. Neurology 54, 588-593. doi: 10. 1212/WNL.54.3.588

Akiyama, H., Ikeda, K., Kondo, H., and McGeer, P. L. (1992). Thrombin accumulation in brains of patients with Alzheimer's disease. Neurosci. Lett. 146, 152-154. doi: 10.1016/0304-3940(92)90065-f

Askarova, S., Yang, X., Sheng, W., Sun, G. Y., and Lee, J. C. (2011). Role of A $\beta$ receptor for advanced glycation endproducts interaction in oxidative stress and cytosolic phospholipase $\mathrm{A}_{2}$ activation in astrocytes and cerebral endothelial cells. Neuroscience 199, 375-385. doi: 10.1016/j.neuroscience.2011.09.038

Bailey, T. L., Rivara, C. B., Rocher, A. B., and Hof, P. R. (2004). The nature and effects of cortical microvascular pathology in aging and Alzheimer's disease. Neurol. Res. 26, 573-578. doi: 10.1179/016164104225016272

Beckman, J. S., and Koppenol, W. H. (1996). Nitric oxide, superoxide and peroxynitrite: the good, the bad and ugly. Am. J. Physiol. 271, C1424-C1437.

Beher, D., Hesse, L., Masters, C. L., and Multhaup, G. (1996). Regulation of amyloid protein precursor (APP) binding to collagen and mapping of the binding sites on APP and collagen type I. J. Biol. Chem. 271, 1613-1620. doi: 10.1074/jbc.271. 3.1613

Bell, R. D., and Zlokovic, B. V. (2009). Neurovascular mechanisms and blood-brain barrier disorder in Alzheimer's disease. Acta Neuropathol. 118, 103-113. doi: 10. 1007/s00401-009-0522-3

Berridge, M. J. (2013). Dysregulation of neural calcium signaling in Alzheimer disease, bipolar disorder and schizophrenia. Prion 7, 2-13. doi: 10.4161/pri. 21767

Blennow, K., Dubois, B., Fagan, A. M., Lewczuk, P., de Leon, M. J., and Hampel, H. (2015). Clinical utility of cerebrospinal fluid biomarkers in the diagnosis of early Alzheimer's disease. Alzheimers Dement. 11, 58-69. doi: 10.1016/j.jalz.2014. 02.004

Bloom, G. S. (2014). Amyloid- $\beta$ and tau: the trigger and bullet in Alzheimer disease pathogenesis. JAMA Neurol. 71, 505-508. doi: 10.1001/jamaneurol.2013.5847

Bongioanni, P., Gemignani, F., Boccardi, B., Borgna, M., and Rossi, B. (1997). Platelet monoamine oxidase molecular activity in demented patients. Ital. J. Neurol. Sci. 18, 151-156. doi: 10.1007/bf02048483

Borroni, B., Agosti, C., Marcello, E., Di Luca, M., and Padovani, A. (2010). Blood cell markers in Alzheimer disease: amyloid precursor protein form ratio in platelets. Exp. Gerontol. 45, 53-56. doi: 10.1016/j.exger.2009.08.004

Borroni, B., Akkawi, N., Martini, G., Colciaghi, F., Prometti, P., Rozzini, L., et al. (2002a). Microvascular damage and platelet abnormalities in early Alzheimer's disease. J. Neurol. Sci. 203-204, 189-193. doi: 10.1016/s0022-510x(02) 00289-7

Borroni, B., Perani, D., Broli, M., Colciaghi, F., Garibotto, V., Paghera, B. C., et al. (2005). Pre-clinical diagnosis of Alzheimer disease combining platelet amyloid precursor protein ratio and rCBF spect analysis. J. Neurol. 252, 1359-1362. doi: 10.1007/s00415-005-0867-z

Borroni, B., Volpi, R., Martini, G., Del Bono, R., Archetti, S., Colciaghi, F., et al. (2002b). Peripheral blood abnormalities in Alzheimer disease: evidence for early endothelial dysfunction. Alzheimer Dis. Assoc. Disord. 16, 150-155. doi: 10. 1097/00002093-200207000-00004

Bosetti, F., Brizzi, F., Barogi, S., Mancuso, M., Siciliano, G., Tendi, E. A., et al. (2002). Cytochrome c oxidase and mitochondrial F1F0-ATPase (ATP synthase) activities in platelets and brain from patients with Alzheimer's disease. Neurobiol. Aging 23, 371-376. doi: 10.1016/s0197-4580(01)00314-1

Breen, K. C., Bruce, M., and Anderton, B. H. (1991). Beta amyloid precursor protein mediates neuronal cell-cell and cell-surface adhesion. J. Neurosci. Res. 28, 90-100. doi: 10.1002/jnr.490280109

Broe, G. A., Grayson, D. A., Creasey, H. M., Waite, L. M., Casey, B. J., Bennett, H. P., et al. (2000). Anti-inflammatory drugs protect against Alzheimer disease at low doses. Arch. Neurol. 57, 1586-1591. doi: 10.1001/archneur.57.11.1586

Brown, W. R., and Thore, C. R. (2011). Review: cerebral microvascular pathology in ageing and neurodegeneration. Neuropathol. Appl. Neurobiol. 37, 56-74. doi: 10. 1111/j.1365-2990.2010.01139.x 
Brundel, M., Heringa, S. M., de Bresser, J., Koek, H. L., Zwanenburg, J. J., Jaap Kappelle, L., et al. (2012). High prevalence of cerebral microbleeds at 7Tesla MRI in patients with early Alzheimer's disease. J. Alzheimers Dis. 31, 259-263. doi: 10. 3233/JAD-2012-120364

Buxbaum, J. D., Thinakaran, G., Koliatsos, V., O'Callahan, J., Slunt, H. H., Price, D. L., et al. (1998). Alzheimer amyloid protein precursor in the rat hippocampus: transport and processing through the perforant path. J. Neurosci. 18, 9629-9637.

Cai, H., Griendling, K. K., and Harrison, D. G. (2003). The vascular NAD(P)H oxidases as therapeutic targets in cardiovascular diseases. Trends Pharmacol. Sci. 24, 471-478. doi: 10.1016/s0165-6147(03)00233-5

Canobbio, I., Catricalà, S., Balduini, C., and Torti, M. (2011). Calmodulin regulates the non-amyloidogenic metabolism of amyloid precursor protein in platelets. Biochim. Biophys. Acta 1813, 500-506. doi: 10.1016/j.bbamcr.2010.12.002

Canobbio, I., Catricalà, S., Di Pasqua, L. G., Guidetti, G., Consonni, A., Manganaro, D., et al. (2013). Immobilized amyloid A $\beta$ peptides support platelet adhesion and activation. FEBS Lett. 587, 2606-2611. doi: 10.1016/j.febslet.2013.06.041

Canobbio, I., Guidetti, G. F., Oliviero, B., Manganaro, D., Vara, D., Torti, M., et al. (2014). Amyloid $\beta$-peptide-dependent activation of human platelets: essential role for $\mathrm{Ca} 2+$ and ADP in aggregation and thrombus formation. Biochem. J. 462, 513-523. doi: 10.1042/BJ20140307

Cardoso, S. M., Proença, M. T., Santos, S., Santana, I., and Oliveira, C. R. (2004). Cytochrome c oxidase is decreased in Alzheimer's disease platelets. Neurobiol. Aging 25, 105-110. doi: 10.1016/s0197-4580(03)00033-2

Carvalho, C., Correia, S. C., Santos, R. X., Cardoso, S., Moreira, P. I., Clark, T. A., et al. (2009). Role of mitochondrial-mediated signaling pathways in Alzheimer disease and hypoxia. J. Bioenerg. Biomembr. 41, 433-440. doi: 10.1007/s10863009-9247-1

Casserly, I. P., and Topol, E. J. (2004). Convergence of atherosclerosis and alzheimer's disease: cholesterol, inflammation and misfolded proteins. Discov. Med. 4, 149-156.

Catricalà, S., Torti, M., and Ricevuti, G. (2012). Alzheimer disease and platelets: how's that relevant. Immun. Ageing 9:20. doi: 10.1186/1742-4933-9-20

Chi, N. F., Chien, L. N., Ku, H. L., Hu, C. J., and Chiou, H. Y. (2013). Alzheimer disease and risk of stroke: a population-based cohort study. Neurology 80, 705-711. doi: 10.1212/WNL.0b013e31828250af

Christov, A., Ottman, J., Hamdheydari, L., and Grammas, P. (2008). Structural changes in Alzheimer's disease brain microvessels. Curr. Alzheimer Res. 5, 392-395. doi: 10.2174/156720508785132334

Colciaghi, F., Borroni, B., Pastorino, L., Marcello, E., Zimmermann, M., Cattabeni, F., et al. (2002). [alpha]-Secretase ADAM10 as well as [alpha]APPs is reduced in platelets and CSF of Alzheimer disease patients. Mol. Med. 8, 67-74.

Colciaghi, F., Marcello, E., Borroni, B., Zimmermann, M., Caltagirone, C., Cattabeni, F., et al. (2004). Platelet APP, ADAM 10 and BACE alterations in the early stages of Alzheimer disease. Neurology 62, 498-501. doi: 10.1212/01.wnl. $0000106953.49802 .9 \mathrm{c}$

Cortes-Canteli, M., Paul, J., Norris, E. H., Bronstein, R., Ahn, H. J., Zamolodchikov, D., et al. (2010). Fibrinogen and beta-amyloid association alters thrombosis and fibrinolysis: a possible contributing factor to Alzheimer's disease. Neuron 66, 695-709. doi: 10.1016/j.neuron.2010.05.014

Dale, G. L. (2005). Coated-platelets: an emerging component of the procoagulant response. J. Thromb. Haemost. 3, 2185-2192. doi: 10.1111/j.1538-7836.2005. 01274.x

Davies, T. A., Long, H. J., Eisenhauer, P. B., Hastey, R., Cribbs, D. H., Fine, R. E., et al. (2000). Beta amyloid fragments derived from activated platelets deposit in cerebrovascular endothelium: usage of a novel blood brain barrier endothelial cell model system. Amyloid 7, 153-165. doi: 10.3109/13506120009146830

Deane, R., Du Yan, S., Submamaryan, R. K., LaRue, B., Jovanovic, S., Hogg, E., et al. (2003). RAGE mediates amyloid-beta peptide transport across the bloodbrain barrier and accumulation in brain. Nat. Med. 9, 907-913. doi: 10.1038/ nm890

Deane, R., Wu, Z., and Zlokovic, B. V. (2004). RAGE (yin) versus LRP (yang) balance regulates alzheimer amyloid beta-peptide clearance through transport across the blood-brain barrier. Stroke 35, 2628-2631. doi: 10.1161/01.str. 0000143452.85382.dl

De Bock, M., Wang, N., Decrock, E., Bol, M., Gadicherla, A. K., Culot, M., et al. (2013). Endothelial calcium dynamics, connexin channels and blood-brain barrier function. Prog. Neurobiol. 108, 1-20. doi: 10.1016/j.pneurobio.2013. 06.001
DeFronzo, R. A., and Ferrannini, E. (1991). Insulin resistance. A multifaceted syndrome responsible for NIDDM, obesity, hypertension, dyslipidemia and atherosclerotic cardiovascular disease. Diabetes Care 14, 173-194. doi: 10. 2337/diacare.14.3.173

de la Torre, J. C. (2000). Critically attained threshold of cerebral hypoperfusion: the CATCH hypothesis of Alzheimer's pathogenesis. Neurobiol. Aging 21, 331-342. doi: 10.1016/s0197-4580(00)00111-1

de la Torre, J. C. (2004a). Alzheimer's disease is a vasocognopathy: a new term to describe its nature. Neurol. Res. 26, 517-524. doi: 10.1179/0161641042250 16254

de la Torre, J. C. (2004b). Is Alzheimer's disease a neurodegenerative or a vascular disorder? Data, dogma, and dialectics. Lancet Neurol. 3, 184-190. doi: 10. 1016/S1474-4422(04)00683-0

de la Torre, J. C. (2010). Vascular risk factor detection and control may prevent Alzheimer's disease. Ageing Res. Rev. 9, 218-225. doi: 10.1016/j.arr.2010.04.002

de la Torre, J. C., and Mussivand, T. (1993). Can disturbed brain microcirculation cause Alzheimer's disease? Neurol. Res. 15, 146-153.

Demuro, A., Mina, E., Kayed, R., Milton, S. C., Parker, I., and Glabe, C. G. (2005). Calcium dysregulation and membrane disruption as a ubiquitous neurotoxic mechanism of soluble amyloid oligomers. J. Biol. Chem. 280, 17294-17300. doi: 10.1074/jbc.m500997200

Di Luca, M., Colciaghi, F., Pastorino, L., Borroni, B., Padovani, A., and Cattabeni, F. (2000). Platelets as a peripheral district where to study pathogenetic mechanisms of alzheimer disease: the case of amyloid precursor protein. Eur. J. Pharmacol. 405, 277-283. doi: 10.1016/s0014-2999(00)00559-8

Esch, F. S., Keim, P. S., Beattie, E. C., Blacher, R. W., Culwell, A. R., Oltersdorf, T., et al. (1990). Cleavage of amyloid beta peptide during constitutive processing of its precursor. Science 248, 1122-1124. doi: 10.1126/science.2111583

Evin, G., Zhu, A., Holsinger, R. M., Masters, C. L., and Li, Q. X. (2003). Proteolytic processing of the Alzheimer's disease amyloid precursor protein in brain and platelets. J. Neurosci. Res. 74, 386-392. doi: 10.1002/jnr.10745

Farkas, E., and Luiten, P. G. (2001). Cerebral microvascular pathology in aging and Alzheimer's disease. Prog. Neurobiol. 64, 575-611. doi: 10.1016/s03010082(00)00068-x

Fonseca, A. C., Ferreiro, E., Oliveira, C. R., Cardoso, S. M., and Pereira, C. F. (2013). Activation of the endoplasmic reticulum stress response by the amyloid-beta 1-40 peptide in brain endothelial cells. Biochim. Biophys. Acta 1832, 2191-2203. doi: 10.1016/j.bbadis.2013.08.007

Fonseca, A. C., Moreira, P. I., Oliveira, C. R., Cardoso, S. M., Pinton, P., and Pereira, C. F. (2014). Amyloid-Beta disrupts calcium and redox homeostasis in brain endothelial cells. Mol. Neurobiol. doi: 10.1007/s12035-014-8740-7. [Epub ahead of print].

Freedman, J. E. (2008). Oxidative stress and platelets. Arterioscler. Thromb. Vasc. Biol. 28, s11-s16. doi: 10.1161/ATVBAHA.107.159178

Galeazzi, L., Casoli, T., Giunta, S., Fattoretti, P., Gracciotti, N., Caselli, U., et al. (2000). $\beta$-amyloid fragment 25-35 induces changes in cytosolic free calcium in human platelets. Ann. N Y Acad. Sci. 903, 451-456. doi: 10.1111/j.1749-6632. 2000.tb06398.x

Gandy, S. (2005). The role of cerebral amyloid $\beta$ accumulation in common forms of Alzheimer disease. J. Clin. Invest. 115, 1121-1129. doi: 10.1172/jci200525100

Garwood, C., Faizullabhoy, A., Wharton, S. B., Ince, P. G., Heath, P. R., Shaw, P. J., et al. (2013). Calcium dysregulation in relation to Alzheimer-type pathology in the ageing brain. Neuropathol. Appl. Neurobiol. 39, 788-799. doi: 10.1111/nan. 12033

Ghiso, J., Rostagno, A., Gardella, J. E., Liem, L., Gorevic, P. D., and Frangione, B. (1992). A 109-amino-acid C-terminal fragment of Alzheimer's-disease amyloid precursor protein contains a sequence, -RHDS-, that promotes cell adhesion. Biochem. J. 288, 1053-1059.

Giri, R., Shen, Y., Stins, M., Du Yan, S., Schmidt, A. M., Stern, D., et al. (2000). Beta-amyloid-induced migration of monocytes across human brain endothelial cells involves RAGE and PECAM-1. Am. J. Physiol. Cell Physiol. 279, C1772-C1781.

Glabe, C. G. (2006). Common mechanisms of amyloid oligomer pathogenesis in degenerative disease. Neurobiol. Aging 27, 570-575. doi: 10.1016/j. neurobiolaging.2005.04.017

Glenner, G. G., and Wong, C. W. (1984). Alzheimer's disease: initial report of the purification and characterization of a novel cerebrovascular amyloid protein. Biochem. Biophys. Res. Commun. 120, 885-890. doi: 10.1016/s0006$291 \times(84) 80190-4$ 
Gorelick, P. B. (2004). Risk factors for vascular dementia and Alzheimer disease. Stroke 35, 2620-2622. doi: 10.1161/01.str.0000143318.70292.47

Gowert, N. S., Donner, L., Chatterjee, M., Eisele, Y. S., Towhid, S. T., Münzer, P., et al. (2014). Blood platelets in the progression of Alzheimer's disease. PLoS One 9:e90523. doi: 10.1371/journal.pone.0090523

Grammas, P. (2011). Neurovascular dysfunction, inflammation and endothelial activation: implications for the pathogenesis of Alzheimer's disease. J. Neuroinflammation 8:26. doi: 10.1186/1742-2094-8-26

Grammas, P., Botchlet, T., Fugate, R., Ball, M. J., and Roher, A. E. (1995). Alzheimer disease amyloid proteins inhibit brain endothelial cell proliferation in vitro. Dementia 6, 126-130. doi: 10.1159/000106934

Grammas, P., Martinez, J., Sanchez, A., Yin, X., Riley, J., Gay, D., et al. (2014). A new paradigm for the treatment of Alzheimer's disease: targeting vascular activation. J. Alzheimers Dis. 40, 619-630. doi: 10.3233/JAD-2014-132057

Grammas, P., and Ovase, R. (2001). Inflammatory factors are elevated in brain microvessels in Alzheimer's disease. Neurobiol. Aging 22, 837-842. doi: 10. 1016/s0197-4580(01)00276-7

Grammas, P., Yamada, M., and Zlokovic, B. (2002). The cerebromicrovasculature: a key player in the pathogenesis of Alzheimer's disease. J. Alzheimers Dis. 4, 217-223.

Hardy, J. A., and Higgins, G. A. (1992). Alzheimer's disease: the amyloid cascade hypothesis. Science 256, 184-185. doi: 10.1126/science.1566067

Hardy, J., and Selkoe, D. J. (2002). The amyloid hypothesis of Alzheimer's disease: progress and problems on the road to therapeutics. Science 297, 353-356. doi: 10.1126/science.1072994

Hayashi, S., Sato, N., Yamamoto, A., Ikegame, Y., Nakashima, S., Ogihara, T., et al. (2009). Alzheimer disease-associated peptide, amyloid beta40, inhibits vascular regeneration with induction of endothelial autophagy. Arterioscler. Thromb. Vasc. Biol. 29, 1909-1915. doi: 10.1161/ATVBAHA.109.188516

Henderson, A. S., Jorm, A. F., Christensen, H., Jacomb, P. A., and Korten, A. E. (1997). Aspirin, anti-inflammatory drugs and risk of dementia. Int. J. Geriatr. Psychiatry 12, 926-930. doi: 10.1002/(sici)1099-1166(199709)12:9<926::aidgps665>3.3.co;2-p

Henry, A., Li, Q. X., Galatis, D., Hesse, L., Multhaup, G., Beyreuther, K., et al. (1998). Inhibition of platelet activation by the Alzheimer's disease amyloid precursor protein. Br. J. Haematol. 103, 402-415. doi: 10.1046/j.1365-2141.1998. 01005.x

Herczenik, E., Bouma, B., Korporaal, S. J., Strangi, R., Zeng, Q., Gros, P., et al. (2007). Activation of human platelets by misfolded proteins. Arterioscler. Thromb. Vasc. Biol. 27, 1657-1665. doi: 10.1161/atvbaha.107.143479

Honjo, K., Black, S. E., and Verhoeff, N. P. (2012). Alzheimer's disease, cerebrovascular disease and the $\beta$-amyloid cascade. Can. J. Neurol. Sci. 39, 712-728. doi: 10.1017/s0317167100015547

Ikonomovic, M. D., Klunk, W. E., Abrahamson, E. E., Mathis, C. A., Price, J. C., Tsopelas, N. D., et al. (2008). Post-mortem correlates of in vivo PiB-PET amyloid imaging in a typical case of Alzheimer's disease. Brain 131, 1630-1645. doi: 10. 1093/brain/awn016

in 't Veld, B. A., Launer, L. J., Breteler, M. M., Hofman, A., and Stricker, B. H. (2002). Pharmacologic agents associated with a preventive effect on Alzheimer's disease: a review of the epidemiologic evidence. Epidemiol. Rev. 24, 248-268. doi: 10.1093/epirev/mxf001

Iwatsubo, T. (2004). The gamma-secretase complex: machinery for intramembrane proteolysis. Curr. Opin. Neurobiol. 14, 379-383. doi: 10.1016/s09594388(04)00077-7

Jarre, A., Gowert, N. S., Donner, L., Münzer, P., Klier, M., Borst, O., et al. (2014). Pre-activated blood platelets and a pro-thrombotic phenotype in APP23 mice modeling Alzheimer's disease. Cell. Signal. 26, 2040-2050. doi: 10.1016/j.cellsig. 2014.05.019

Jellinger, K. A. (2002). Alzheimer disease and cerebrovascular pathology: an update. J. Neural Transm. 109, 813-836. doi: 10.1007/s007020200068

Jellinger, K. A. (2010). Prevalence and impact of cerebrovascular lesions in Alzheimer and lewy body diseases. Neurodegener. Dis. 7, 112-115. doi: 10. $1159 / 000285518$

Johnston, J. A., Liu, W. W., Coulson, D. T., Todd, S., Murphy, S., Brennan, S., et al. (2008). Platelet beta-secretase activity is increased in Alzheimer's disease. Neurobiol. Aging 29, 661-668. doi: 10.1016/j.neurobiolaging.2006.11.003

Kalaria, R. N. (2010). Vascular basis for brain degeneration: faltering controls and risk factors for dementia. Nutr. Rev. 68(Suppl. 2), S74-S87. doi: 10.1111/j.17534887.2010.00352.x
Kalaria, R. N., and Pax, A. B. (1995). Increased collagen content of cerebral microvessels in Alzheimer's disease. Brain Res. 705, 349-352. doi: 10.1016/00068993(95)01250-8

Kaminsky, Y. G., Marlatt, M. W., Smith, M. A., and Kosenko, E. A. (2010). Subcellular and metabolic examination of amyloid-beta peptides in Alzheimer disease pathogenesis: evidence for A $\beta$ (25-35). Exp. Neurol. 221, 26-37. doi: 10. 1016/j.expneurol.2009.09.005

Kang, J., Lemaire, H. G., Unterbeck, A., Salbaum, J. M., Masters, C. L., Grzeschik, K. H., et al. (1987). The precursor of Alzheimer's disease amyloid A4 protein resembles a cell-surface receptor. Nature 325, 733-736. doi: 10.1038/32 $5733 \mathrm{a} 0$

Kara, F., Dongen, E. S., Schliebs, R., Buchem, M. A., Groot, H. J., and Alia, A. (2012). Monitoring blood flow alterations in the Tg2576 mouse model of Alzheimer's disease by in vivo magnetic resonance angiography at $17.6 \mathrm{~T}$. Neuroimage 60, 958-966. doi: 10.1016/j.neuroimage.2011.12.055

Kelleher, R. J., and Soiza, R. L. (2013). Evidence of endothelial dysfunction in the development of Alzheimer's disease: is Alzheimer's a vascular disorder? Am. J. Cardiovasc. Dis. 3, 197-226.

Kennedy, J. L., Farrer, L. A., Andreasen, N. C., Mayeux, R., and St George-Hyslop, P. (2003). The genetics of adult-onset neuropsychiatric disease: complexities and conundra? Science 302, 822-826. doi: 10.1126/science.1092132

Kitazume, S., Yoshihisa, A., Yamaki, T., Oikawa, M., Tachida, Y., Ogawa, K., et al. (2012). Soluble amyloid precursor protein 770 is released from inflamed endothelial cells and activated platelets: a novel biomarker for acute coronary syndrome. J. Biol. Chem. 287, 40817-40825. doi: 10.1074/jbc.M112.398578

Kokjohn, T. A., Van Vickle, G. D., Maarouf, C. L., Kalback, W. M., Hunter, J. M., Daugs, I. D., et al. (2011). Chemical characterization of pro-inflammatory amyloid-beta peptides in human atherosclerotic lesions and platelets. Biochim. Biophys. Acta 1812, 1508-1514. doi: 10.1016/j.bbadis.2011.07.004

Kook, S. Y., Hong, H. S., Moon, M., Ha, C. M., Chang, S., and Mook-Jung, I. (2012). A $\beta_{1-42}$-RAGE interaction disrupts tight junctions of the blood-brain barrier via $\mathrm{Ca}^{2+}$-calcineurin signaling. J. Neurosci. 32, 8845-8854. doi: 10 . 1523/JNEUROSCI.6102-11.2012

Kuo, Y. M., Kokjohn, T. A., Watson, M. D., Woods, A. S., Cotter, R. J., Sue, L. I., et al. (2000). Elevated abeta42 in skeletal muscle of Alzheimer disease patients suggests peripheral alterations of AbetaPP metabolism. Am. J. Pathol. 156, 797-805. doi: 10.1016/s0002-9440(10)64947-4

Laske, C. (2012). Alzheimer disease: blood-based biomarkers in AD-a silver lining on the horizon. Nat. Rev. Neurol. 8, 541-542. doi: 10.1038/nrneurol.2012.173

Laske, C., Sopova, K., Gkotsis, C., Eschweiler, G. W., Straten, G., Gawaz, M., et al. (2010). Amyloid- $\beta$ peptides in plasma and cognitive decline after 1 year followup in Alzheimer's disease patients. J. Alzheimers Dis. 21, 1263-1269.

Lee, H. G., Casadesus, G., Zhu, X., Joseph, J. A., Perry, G., and Smith, M. A. (2004). Perspectives on the amyloid-beta cascade hypothesis. J. Alzheimers Dis. 6, 137-145.

Lee, M. J., Seo, S. W., Na, D. L., Kim, C., Park, J. H., Kim, G. H., et al. (2014). Synergistic effects of ischemia and $\beta$-amyloid burden on cognitive decline in patients with subcortical vascular mild cognitive impairment. JAMA Psychiatry 71, 412-422. doi: 10.1001/jamapsychiatry.2013.4506

Leo, R., Praticò, D., Iuliano, L., Pulcinelli, F. M., Ghiselli, A., Pignatelli, P., et al. (1997). Platelet activation by superoxide anion and hydroxyl radicals intrinsically generated by platelets that had undergone anoxia and then reoxygenated. Circulation 95, 885-891. doi: 10.1161/01.cir.95.4.885

Li, Q. X., Berndt, M. C., Bush, A. I., Rumble, B., Mackenzie, I., and Friedhuber, A. (1994). Membrane-associated forms of the beta A4 amyloid protein precursor of Alzheimer's disease in human platelet and brain: surface expression on the activated human platelet. Blood 84, 133-142.

Li, J. C., Han, L., Wen, Y. X., Yang, Y. X., Li, S., Li, X. S., et al. (2015). Increased permeability of the blood-brain barrier and Alzheimer's disease-like alterations in slit-2 transgenic mice. J. Alzheimers Dis. 43, 535-548. doi: 10.3233/JAD141215

Li, M., Shang, D. S., Zhao, W. D., Tian, L., Li, B., Fang, W. G., et al. (2009). Amyloid beta interaction with receptor for advanced glycation end products up-regulates brain endothelial CCR5 expression and promotes $\mathrm{T}$ cells crossing the blood-brain barrier. J. Immunol. 182, 5778-5788. doi: 10.4049/jimmunol.08 03013

Li, Q. X., Whyte, S., Tanner, J. E., Evin, G., Beyreuther, K., and Masters, C. L. (1998). Secretion of Alzheimer's disease Abeta amyloid peptide by activated human platelets. Lab. Invest. 78, 461-469. 
Liu, W. W., Todd, S., Craig, D., Passmore, A. P., Coulson, D. T., Murphy, S., et al. (2007). Elevated platelet $\beta$-secretase activity in mild cognitive impairment. Dement. Geriatr. Cogn. Disord. 24, 464-468. doi: 10.1159/000110739

Loll, P. J., Picot, D., and Garavito, R. M. (1995). The structural basis of aspirin activity inferred from the crystal structure of inactivated prostaglandin H2 synthase. Nat. Struct. Biol. 2, 637-643. doi: 10.1038/nsb0895-637

Lorenzo, A., Yuan, M., Zhang, Z., Paganetti, P. A., Sturchler-Pierrat, C., Staufenbiel, M., et al. (2000). Amyloid beta interacts with the amyloid precursor protein: a potential toxic mechanism in Alzheimer's disease. Nat. Neurosci. 3, 460-464. doi: $10.1038 / 74833$

Lue, L. F., Walker, D. G., Brachova, L., Beach, T. G., Rogers, J., Schmidt, A. M., et al. (2001). Involvement of microglial receptor for advanced glycation endproducts (RAGE) in Alzheimer's disease: identification of a cellular activation mechanism. Exp. Neurol. 171, 29-45. doi: 10.1006/exnr.2001.7732

Menting, K. W., and Claassen, J. A. (2014). $\beta$-secretase inhibitor; a promising novel therapeutic drug in Alzheimer's disease. Front. Aging Neurosci. 6:165. doi: 10. 3389/fnagi.2014.00165

Mészáros, Z., Borcsiczky, D., Máté, M., Tarcali, J., Szombathy, T., Tekes, K., et al. (1998). Platelet MAO-B activity and serotonin content in patients with dementia: effect of age, medication and disease. Neurochem. Res. 23, 863-868. doi: 10.1023/A:1022458928442

Mhatre, M., Nguyen, A., Kashani, S., Pham, T., Adesina, A., and Grammas, P. (2004). Thrombin, a mediator of neurotoxicity and memory impairment. Neurobiol. Aging 25, 783-793. doi: 10.1016/s0197-4580(03)00192-1

Michaelson, D. M. (2014). APOE $\epsilon 4$ : the most prevalent yet understudied risk factor for Alzheimer's disease. Alzheimers Dement. 10, 861-868. doi: 10.1016/j. jalz.2014.06.015

Miller, T. W., Isenberg, J. S., Shih, H. B., Wang, Y., and Roberts, D. D. (2010). Amyloid- $\beta$ inhibits No-cGMP signaling in a CD36- and CD47-dependent manner. PLoS One 5:e15686. doi: 10.1371/journal.pone.0015686

Milward, E. A., Papadopoulos, R., Fuller, S. J., Moir, R. D., Small, D., Beyreuther, K., et al. (1992). The amyloid protein precursor of Alzheimer's disease is a mediator of the effects of nerve growth factor on neurite outgrowth. Neuron 9, 129-137. doi: 10.1016/0896-6273(92)90228-6

Molnar, F. J., Man-Son-Hing, M., St John, P., Brymer, C., Rockwood, K., and Hachinski, V. (1998). Subcortical vascular dementia: survey of treatment patterns and research considerations. Can. J. Neurol. Sci. 25, 320-324.

Morris, J. K., Honea, R. A., Vidoni, E. D., Swerdlow, R. H., and Burns, J. M. (2014). Is Alzheimer's disease a systemic disease?. Biochim. Biophys. Acta 1842, 1340 1349. doi: 10.1016/j.bbadis.2014.04.012

Murphy, M. P., and LeVine, H. 3rd (2010). Alzheimer's disease and the amyloidbeta peptide. J. Alzheimers Dis. 19, 311-323. doi: 10.3233/JAD-2010-1221

Nakayama, K., Nagase, H., Koh, C. S., and Ohkawara, T. (2011). $\gamma$-Secretaseregulated mechanisms similar to notch signaling may play a role in signaling events, including APP signaling, which leads to Alzheimer's disease. Cell. Mol. Neurobiol. 31, 887-900. doi: 10.1007/s10571-011-9688-Z

Okamoto, T., Takeda, S., Murayama, Y., Ogata, E., and Nishimoto, I. (1995). Ligand-dependent $\mathrm{G}$ protein coupling function of amyloid transmembrane precursor. J. Biol. Chem. 270, 4205-4208. doi: 10.1074/jbc.270.9.4205

Paasonen, M. K., Solatunturi, E., and Kivalo, E. (1964). Monoamine oxidase activity of blood platelets and their ability to store 5-hydroxytryptamine in some mental deficiencies. Psychopharmacologia 6, 120-124. doi: 10.1007/bf00413224

Paris, D., Patel, N., DelleDonne, A., Quadros, A., Smeed, R., and Mullan, M. (2004). Impaired angiogenesis in a transgenic mouse model of cerebral amyloidosis. Neurosci. Lett. 366, 80-85. doi: 10.1016/j.neulet.2004.05.017

Park, L., Anrather, J., Zhou, P., Frys, K., Pitstick, R., Younkin, S., et al. (2005). NADPH-oxidase-derived reactive oxygen species mediate the cerebrovascular dysfunction induced by the amyloid beta peptide. J. Neurosci. 25, 1769-1777. doi: 10.1523/jneurosci.5207-04.2005

Park, K. W., and Jin, B. K. (2008). Thrombin-induced oxidative stress contributes to the death of hippocampal neurons: role of neuronal NADPH oxidase. J. Neurosci. Res. 86, 1053-1063. doi: 10.1002/jnr.21571

Paul, J., Strickland, S., and Melchor, J. P. (2007). Fibrin deposition accelerates neurovascular damage and neuroinflammation in mouse models of Alzheimer's disease. J. Exp. Med. 204, 1999-2008. doi: 10.1084/jem.20070304

Pogue, A. I., and Lukiw, W. J. (2004). Angiogenic signaling in Alzheimer's disease. Neuroreport 15, 1507-1510. doi: 10.1097/01.wnr.0000130539.39937.1d

Pollard, H. B., Rojas, E., and Arispe, N. (1993). A new hypothesis for the mechanism of amyloid toxicity, based on the calcium channel activity of amyloid beta protein (A $\beta$ P) in phospholipid bilayer membranes. Ann. N Y Acad. Sci. 695, 165-168. doi: 10.1111/j.1749-6632.1993.tb23046.x

Price, J. M., Chi, X., Hellermann, G., and Sutton, E. T. (2001). Physiological levels of beta-amyloid induce cerebral vessel dysfunction and reduce endothelial nitric oxide production. Neurol. Res. 23, 506-512. doi: 10.1179/0161641011011 98758

Prodan, C. I., Ross, E. D., Vincent, A. S., and Dale, G. L. (2007). Coatedplatelets are higher in amnestic versus nonamnestic patients with mild cognitive impairment. Alzheimer Dis. Assoc. Disord. 21, 259-261. doi: 10.1097/wad. 0b013e31811ec11f

Prodan, C. I., Ross, E. D., Vincent, A. S., and Dale, G. L. (2008). Rate of progression in Alzheimer's disease correlates with coated-platelet levels-a longitudinal study. Transl. Res. 152, 99-102. doi: 10.1016/j.trsl.2008.07.001

Prodan, C. I., Szasz, R., Vincent, A. S., Ross, E. D., and Dale, G. L. (2006). Coatedplatelets retain amyloid precursor protein on their surface. Platelets 17, 56-60. doi: 10.1080/09537100500181913

Prodan, C. I., Vincent, A. S., Padmanabhan, R., and Dale, G. L. (2009). Coatedplatelet levels are low in patients with spontaneous intracerebral hemorrhage. Stroke 40, 2578-2580. doi: 10.1161/STROKEAHA.109.549014

Purandare, N., and Burns, A. (2009). Cerebral emboli in the genesis of dementia. J. Neurol. Sci. 283, 17-20. doi: 10.1016/j.jns.2009.02.306

Rao, H. V., Thirumangalakudi, L., and Grammas, P. (2009). Cyclin C and cyclin dependent kinases 1, 2 and 3 in thrombin-induced neuronal cell cycle progression and apoptosis. Neurosci. Lett. 450, 347-350. doi: 10.1016/j.neulet. 2008.12.018

Reznik-Wolf, H., Machado, J., Haroutunian, V., DeMarco, L., Walter, G. F., and Goldman, B. (1998). Somatic mutation analysis of the APP and Presenilin 1 and 2 genes in Alzheimer's disease brains. J. Neurogenet. 12, 55-65. doi: 10. 3109/01677069809108555

Roher, A. E., Esh, C. L., Kokjohn, T. A., Castaño, E. M., Van Vickle, G. D., Kalback, W. M., et al. (2009). Amyloid beta peptides in human plasma and tissues and their significance for Alzheimer's disease. Alzheimers Dement. 5, 18-29. doi: 10. 1016/j.jalz.2008.10.004

Roher, A. E., Esh, C., Kokjohn, T. A., Kalback, W., Luehrs, D. C., Seward, J. D., et al. (2003). Circle of willis atherosclerosis is a risk factor for sporadic Alzheimer's disease. Arterioscler. Thromb. Vasc. Biol. 23, 2055-2062. doi: 10.1161/01.atv. 0000095973.42032 .44

Rowley, J. W., Oler, A. J., Tolley, N. D., Hunter, B. N., Low, E. N., Nix, D. A., et al. (2011). Genome-wide RNA-seq analysis of human and mouse platelet transcriptomes. Blood 118, e101-e111. doi: 10.1182/blood-2011-03-339705

Sakurai, H., Hanyu, H., Sato, T., Kume, K., Hirao, K., Kanetaka, H., et al. (2013). Effects of cilostazol on cognition and regional cerebral blood flow in patients with Alzheimer's disease and cerebrovascular disease: a pilot study. Geriatr. Gerontol. Int. 13, 90-97. doi: 10.1111/j.1447-0594.2012.00866.x

Sasaki, N., Toki, S., Chowei, H., Saito, T., Nakano, N., Hayashi, Y., et al. (2001). Immunohistochemical distribution of the receptor for advanced glycation end products in neurons and astrocytes in Alzheimer's disease. Brain Res. 888, 256-262. doi: 10.1016/s0006-8993(00)03075-4

Scandura, J. M., Zhang, Y., Van Nostrand, W. E., and Walsh, P. N. (1997). Progress curve analysis of the kinetics with which blood coagulation factor XIa is inhibited by protease nexin-2. Biochemistry 36, 412-420. doi: 10.1021/bi9612576

Scheuermann, S., Hambsch, B., Hesse, L., Stumm, J., Schmidt, C., Beher, D., et al. (2001). Homodimerization of amyloid precursor protein and its implication in the amyloidogenic pathway of Alzheimer's disease. J. Biol. Chem. 276, 33923-33929. doi: 10.1074/jbc.m105410200

Schmaier, A. H., Dahl, L. D., Hasan, A. A., Cines, D. B., Bauer, K. A., and Van Nostrand, W. E. (1995). Factor IXa inhibition by protease nexin-2/amyloid betaprotein precursor on phospholipid vesicles and cell membranes. Biochemistry 34, 1171-1178. doi: 10.1021/bi00004a010

Seubert, P., Vigo-Pelfrey, C., Esch, F., Lee, M., Dovey, H., Davis, D., et al. (1992). Isolation and quantification of soluble Alzheimer's beta-peptide from biological fluids. Nature 359, 325-327. doi: 10.1038/359325a0

Sevush, S., Jy, W., Horstman, L. L., Mao, W. W., Kolodny, L., and Ahn, Y. S. (1998). Platelet activation in Alzheimer disease. Arch. Neurol. 55, 530-536. doi: 10. 1001/archneur.55.4.530

Shen, M. Y., Hsiao, G., Fong, T. H., Chen, H. M., Chou, D. S., Lin, C. H., et al. (2008a). Amyloid beta peptide-activated signal pathways in human platelets. Eur. J. Pharmacol. 588, 259-266. doi: 10.1016/j.ejphar.2008. 04.040 
Shen, M. Y., Hsiao, G., Fong, T. H., Chou, D. S., and Sheu, J. R. (2008b). Expression of amyloid beta peptide in human platelets: pivotal role of the phospholipase Cgamma2-protein kinase C pathway in platelet activation. Pharmacol. Res. 57, 151-158. doi: 10.1016/j.phrs.2008.01.004

Smirnova, I. V., Zhang, S. X., Citron, B. A., Arnold, P. M., and Festoff, B. W. (1998). Thrombin is an extracellular signal that activates intracellular death protease pathways inducing apoptosis in model motor neurons. J. Neurobiol. 36, 64-80. doi: 10.1002/(sici)1097-4695(199807)36:1<64::aid-neu6>3.3. co;2-4

Smith, R. P., Higuchi, D. A., and Broze, G. J. Jr. (1990). Platelet coagulation factor XIa-inhibitor, a form of Alzheimer amyloid precursor protein. Science 248, 1126-1128. doi: 10.1126/science.2111585

Smolarkiewicz, M., Skrzypczak, T., and Wojtaszek, P. (2013). The very many faces of presenilins and the $\gamma$-secretase complex. Protoplasma 250, 997-1011. doi: 10. 1007/s00709-013-0494-y

Sola Vigo, F., Kedikian, G., Heredia, L., Heredia, F., Añel, A. D., Rosa, A. L., et al. (2009). Amyloid-beta precursor protein mediates neuronal toxicity of amyloid beta through Go protein activation. Neurobiol. Aging 30, 1379-1392. doi: 10. 1016/j.neurobiolaging.2007.11.017

Sonkar, V. K., Kulkarni, P. P., and Dash, D. (2014). Amyloid $\beta$ peptide stimulates platelet activation through RhoA-dependent modulation of actomyosin organization. FASEB J. 28, 1819-1829. doi: 10.1096/fj.13-243691

Sorrentino, P., Iuliano, A., Polverino, A., Jacini, F., and Sorrentino, G. (2014). The dark sides of amyloid in Alzheimer's disease pathogenesis. FEBS Lett. 588, 641-652. doi: 10.1016/j.febslet.2013.12.038

Stellos, K., Panagiota, V., Kögel, A., Leyhe, T., Gawaz, M., and Laske, C. (2010). Predictive value of platelet activation for the rate of cognitive decline in Alzheimer's disease patients. J. Cereb. Blood Flow Metab. 30, 1817-1820. doi: 10. 1038/jcbfm.2010.140

Stewart, P. A., Hayakawa, K., Akers, M. A., and Vinters, H. V. (1992). A morphometric study of the blood-brain barrier in Alzheimer's disease. Lab. Invest. 67, 734-742.

Stokes, K. Y., Russell, J. M., Jennings, M. H., Alexander, J. S., and Granger, D. N. (2007). Platelet-associated NAD $(\mathrm{P}) \mathrm{H}$ oxidase contributes to the thrombogenic phenotype induced by hypercholesterolemia. Free Radic. Biol. Med. 43, 22-30. doi: 10.1016/j.freeradbiomed.2007.02.027

Suo, Z., Wu, M., Citron, B. A., Palazzo, R. E., and Festoff, B. W. (2003). Rapid tau aggregation and delayed hippocampal neuronal death induced by persistent thrombin signaling. J. Biol. Chem. 278, 37681-37689. doi: 10. 1074/jbc.m301406200

Sutcliffe, J. G., Hedlund, P. B., Thomas, E. A., Bloom, F. E., and Hilbush, B. S. (2011). Peripheral reduction of $\beta$-amyloid is sufficient to reduce brain $\beta$ amyloid: implications for Alzheimer's disease. J. Neurosci. Res. 89, 808-814. doi: 10.1002/jnr.22603

Szekely, C. A., and Zandi, P. P. (2010). Non-steroidal anti-inflammatory drugs and Alzheimer's disease: the epidemiological evidence. CNS Neurol. Disord. Drug Targets. 9, 132-139. doi: 10.2174/187152710791012026

Takuma, K., Fang, F., Zhang, W., Yan, S., Fukuzaki, E., Du, H., et al. (2009). RAGEmediated signaling contributes to intraneuronal transport of amyloid-beta and neuronal dysfunction. Proc. Natl. Acad. Sci. U S A 106, 20021-20026. doi: 10. 1073/pnas.0905686106

Tang, K., Hynan, L. S., Baskin, F., and Rosenberg, R. N. (2006). Platelet amyloid precursor protein processing: a bio-marker for Alzheimer's disease. J. Neurol. Sci. 240, 53-58. doi: 10.1016/j.jns.2005.09.002

Thal, L. J., Ferris, S. H., Kirby, L., Block, G. A., Lines, C. R., Yuen, E., et al. (2005). A randomized, double-blind, study of rofecoxib in patients with mild cognitive impairment. Neuropsychopharmacology 30, 1204-1215. doi: 10.1038/sj.npp. 1300690

Thal, D. R., Ghebremedhin, E., Orantes, M., and Wiestler, O. D. (2003). Vascular pathology in Alzheimer disease: correlation of cerebral amyloid angiopathy and arteriosclerosis/lipohyalinosis with cognitive decline. J. Neuropathol. Exp. Neurol. 62, 1287-1301.

The Lancet Neurology. (2010). How much is dementia care worth? Lancet Neurol. 9:1037. doi: 10.1016/S1474-4422(10)70257-X

Thirumangalakudi, L., Samany, P. G., Owoso, A., Wiskar, B., and Grammas, P. (2006). Angiogenic proteins are expressed by brain blood vessels in Alzheimer's disease. J. Alzheimers Dis. 10, 111-118.

Tibolla, G., Norata, G. D., Meda, C., Arnaboldi, L., Uboldi, P., Piazza, F., et al. (2010). Increased atherosclerosis and vascular inflammation in APP transgenic mice with apolipoprotein E deficiency. Atherosclerosis 210, 78-87. doi: 10.1016/j. atherosclerosis.2009.10.040

Tjernberg, L. O., Callaway, D. J., Tjernberg, A., Hahne, S., Lilliehöök, C., Terenius, L., et al. (1999). A molecular model of Alzheimer amyloid beta-peptide fibril formation. J. Biol. Chem. 274, 12619-12625. doi: 10.1074/jbc.274.18.12619

Tolppanen, A. M., Lavikainen, P., Solomon, A., Kivipelto, M., Soininen, H., and Hartikainen, S. (2013). Incidence of stroke in people with Alzheimer disease: a national register-based approach. Neurology 80, 353-358. doi: 10.1212/WNL. 0b013e31827f08c5

Tripathy, D., Sanchez, A., Yin, X., Luo, J., Martinez, J., and Grammas, P. (2013). Thrombin, a mediator of cerebrovascular inflammation in $\mathrm{AD}$ and hypoxia. Front. Aging Neurosci. 5:19. doi: 10.3389/fnagi.2013.00019

Truran, S., Franco, D. A., Roher, A. E., Beach, T. G., Burciu, C., Serrano, G., et al. (2014). Adipose and leptomeningeal arteriole endothelial dysfunction induced by $\beta$-amyloid peptide: a practical human model to study Alzheimer's disease vasculopathy. J. Neurosci. Methods 235, 123-129. doi: 10.1016/j.jneumeth.2014. 06.014

Tsopanoglou, N. E., Andriopoulou, P., and Maragoudakis, M. E. (2002). On the mechanism of thrombin-induced angiogenesis: involvement of alphavbeta3integrin. Am. J. Physiol. Cell Physiol. 283, C1501-C1510. doi: 10.1152/ajpcell. 00162.2002

Van Nostrand, W. E., and Melchor, J. P. (2001). Disruption of pathologic amyloid beta-protein fibril assembly on the surface of cultured human cerebrovascular smooth muscle cells. Amyloid 8(Suppl. 1), 20-27.

Van Nostrand, W. E., Melchor, J. P., Keane, D. M., Saporito-Irwin, S. M., Romanov, G., Davis, J., et al. (2002). Localization of a fibrillar amyloid beta-protein binding domain on its precursor. J. Biol. Chem. 277, 36392-36398. doi: 10.1074/jbc. $\mathrm{m} 204676200$

Van Nostrand, W. E., Schmaier, A. H., Farrow, J. S., and Cunningham, D. D. (1990). Protease nexin-II (amyloid beta-protein precursor): a platelet alpha-granule protein. Science 248, 745-748. doi: 10.1126/science.2110384

Van Nostrand, W. E., Schmaier, A. H., Neiditch, B. R., Siegel, R. S., Raschke, W. C., Sisodia, S. S., et al. (1994). Expression, purification and characterization of the Kunitz-type proteinase inhibitor domain of the amyloid beta-protein precursorlike protein-2. Biochim. Biophys. Acta 1209, 165-170. doi: 10.1016/01674838(94)90180-5

Van Nostrand, W. E., Schmaier, A. H., and Wagner, S. L. (1992). Potential role of protease nexin-2/amyloid beta-protein precursor as a cerebral anticoagulant. Ann. N Y Acad. Sci. 674, 243-252. doi: 10.1111/j.1749-6632.1992.tb27493.x

Van Nostrand, W. E., Wagner, S. L., Suzuki, M., Choi, B. H., Farrow, J. S., and Geddes, J. W. (1989). Protease nexin-II, a potent antichymotrypsin, shows identity to amyloid beta-protein precursor. Nature 341, 546-549. doi: 10 . 1038/341546a0

Vara, D., Campanella, M., and Pula, G. (2013). The novel NOX inhibitor 2acetylphenothiazine impairs collagen-dependent thrombus formation in a GPVI-dependent manner. Br. J. Pharmacol. 168, 212-224. doi: 10.1111/j.14765381.2012.02130.x

Vassar, R., Kuhn, P. H., Haass, C., Kennedy, M. E., Rajendran, L., Wong, P. C., et al. (2014). Function, therapeutic potential and cell biology of BACE proteases: current status and future prospects. J. Neurochem. 130, 4-28. doi: 10.1111/jnc. 12715

Veitinger, M., Varga, B., Guterres, S. B., and Zellner, M. (2014). Platelets, a reliable source for peripheral Alzheimer's disease biomarkers? Acta Neuropathol. Commun. 2:65. doi: 10.1186/2051-5960-2-65

Verdier, Y., and Penke, B. (2004). Binding sites of amyloid beta-peptide in cell plasma membrane and implications for Alzheimer's disease. Curr. Protein Pept. Sci. 5, 19-31. doi: 10.2174/1389203043486937

Vingtdeux, V., and Marambaud, P. (2012). Identification and biology of $\alpha$-secretase. J. Neurochem. 120(Suppl. 1), 34-45. doi: 10.1111/j.1471-4159.2011.07477.x

Viswanathan, A., and Greenberg, S. M. (2011). Cerebral amyloid angiopathy in the elderly. Ann. Neurol. 70, 871-880. doi: 10.1002/ana.22516

Viswanathan, A., Rocca, W. A., and Tzourio, C. (2009). Vascular risk factors and dementia: how to move forward? Neurology 72, 368-374. doi: 10.1212/01.wnl. $0000341271.90478 .8 \mathrm{e}$

Vukic, V., Callaghan, D., Walker, D., Lue, L. F., Liu, Q. Y., Couraud, P. O., et al. (2009). Expression of inflammatory genes induced by beta-amyloid peptides in human brain endothelial cells and in Alzheimer's brain is mediated by the JNKAP1 signaling pathway. Neurobiol. Dis. 34, 95-106. doi: 10.1016/j.nbd.2008. 12.007 
Wautier, M. P., Chappey, O., Corda, S., Stern, D. M., Schmidt, A. M., and Wautier, J. L. (2001). Activation of NADPH oxidase by AGE links oxidant stress to altered gene expression via RAGE. Am. J. Physiol. Endocrinol. Metab. 280, E685E694.

Wilkerson, W. R., and Sane, D. C. (2002). Aging and thrombosis. Semin. Thromb. Hemost. 28, 555-568. doi: 10.1055/s-2002-36700

Williamson, T. G., Mok, S. S., Henry, A., Cappai, R., Lander, A. D., Nurcombe, V., et al. (1996). Secreted glypican binds to the amyloid precursor protein of Alzheimer's disease (APP) and inhibits APP-induced neurite outgrowth. J. Biol. Chem. 271, 31215-31221. doi: 10.1074/jbc.271.49.31215

World Alzheimer Report. (2011). The Benefits of Early Diagnosis and Intervention. London, UK: Alzheimer's disease International. Available online at: http://www.alz.co.uk/research/world-report-2011

Wu, Z., Guo, H., Chow, N., Sallstrom, J., Bell, R. D., Deane, R., et al. (2005). Role of the MEOX2 homeobox gene in neurovascular dysfunction in Alzheimer disease. Nat. Med. 11, 959-965.

Xu, F., Davis, J., Miao, J., Previti, M. L., Romanov, G., Ziegler, K., et al. (2005). Protease nexin-2/amyloid beta-protein precursor limits cerebral thrombosis. Proc. Natl. Acad. Sci. U S A 102, 18135-18140. doi: 10.1073/pnas.05077 98102

Xu, F., Kotarba, A. E., Ou-Yang, M. H., Fu, Z., Davis, J., Smith, S. O., et al. (2014). Early-onset formation of parenchymal plaque amyloid abrogates cerebral microvascular amyloid accumulation in transgenic mice. J. Biol. Chem. 289, 17895-17908. doi: 10.1074/jbc.M113.536565

Xu, F., Previti, M. L., and Van Nostrand, W. E. (2007). Increased severity of hemorrhage in transgenic mice expressing cerebral protease nexin-2/amyloid beta-protein precursor. Stroke 38, 2598-2601. doi: 10.1161/strokeaha.106. 480103

Yan, S. D., Chen, X., Fu, J., Chen, M., Zhu, H., Roher, A., et al. (1996). RAGE and amyloid-beta peptide neurotoxicity in Alzheimer's disease. Nature 382, 685-691. doi: $10.1038 / 382685 \mathrm{a} 0$

Yeung, J., and Holinstat, M. (2012). Newer agents in antiplatelet therapy: a review. J. Blood Med. 3, 33-42. doi: 10.2147/JBM.S25421
Yin, X., Wright, J., Wall, T., and Grammas, P. (2010). Brain endothelial cells synthesize neurotoxic thrombin in Alzheimer's disease. Am. J. Pathol. 176, 1600-1606. doi: 10.2353/ajpath.2010.090406

Zhang, W., Huang, W., and Jing, F. (2013). Contribution of blood platelets to vascular pathology in Alzheimer's disease. J. Blood Med. 4, 141-147. doi: 10. 2147/JBM.S45071

Zlokovic, B. V. (2005). Neurovascular mechanisms of Alzheimer's neuro -degeneration. Trends Neurosci. 28, 202-208. doi: 10.1016/j.tins.2005.02.001

Zuliani, G., Cavalieri, M., Galvani, M., Passaro, A., Munari, M. R., Bosi, C., et al. (2008). Markers of endothelial dysfunction in older subjects with late onset alzheimer's disease or vascular dementia. J. Neurol. Sci. 272, 164-170. doi: 10.1016/j.jns.2008.05.020

Conflict of Interest Statement: The Guest Associate Editor Francesco Moccia declares that, despite being affiliated to the same institution as authors Ilaria Canobbio, Aisha Alsheikh Abubaker, Caterina Visconte, Mauro Torti and Giordano Pula, the review process was handled objectively and no conflict of interest exists. The authors declare that the research was conducted in the absence of any commercial or financial relationships that could be construed as a potential conflict of interest.

Received: 14 January 2015; accepted: 11 February 2015; published online: 03 March 2015.

Citation: Canobbio I, Abubaker AA, Visconte C, Torti M and Pula G (2015) Role of amyloid peptides in vascular dysfunction and platelet dysregulation in Alzheimer's disease. Front. Cell. Neurosci. 9:65. doi: 10.3389/fncel.2015.00065

This article was submitted to the journal Frontiers in Cellular Neuroscience.

Copyright (c) 2015 Canobbio, Abubaker, Visconte, Torti and Pula. This is an openaccess article distributed under the terms of the Creative Commons Attribution License (CC BY). The use, distribution and reproduction in other forums is permitted, provided the original author(s) or licensor are credited and that the original publication in this journal is cited, in accordance with accepted academic practice. No use, distribution or reproduction is permitted which does not comply with these terms. 